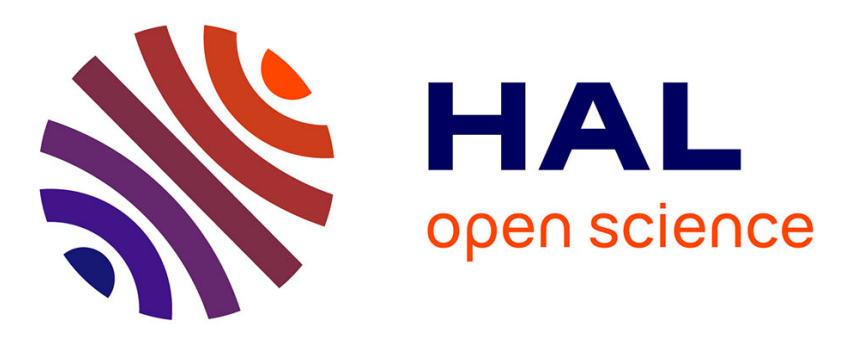

\title{
Crosstalk between Rap1 and Rac regulates secretion of $\operatorname{sAPP} \alpha$
}

Marjorie Maillet, Sylvain J Robert, Mathias Cacquevel, Monique Gastineau, Denis Vivien, Jacques Bertoglio, José L Zugaza, Rodolphe Fischmeister, Frank Lezoualc'H

\section{To cite this version:}

Marjorie Maillet, Sylvain J Robert, Mathias Cacquevel, Monique Gastineau, Denis Vivien, et al.. Crosstalk between Rap1 and Rac regulates secretion of sAPP $\alpha$. Nature Cell Biology, 2003, 5 (7), pp.633-639. 10.1038/ncb1007 . hal-03161427

\section{HAL Id: hal-03161427 https://hal.science/hal-03161427}

Submitted on 6 Mar 2021

HAL is a multi-disciplinary open access archive for the deposit and dissemination of scientific research documents, whether they are published or not. The documents may come from teaching and research institutions in France or abroad, or from public or private research centers.
L'archive ouverte pluridisciplinaire HAL, est destinée au dépôt et à la diffusion de documents scientifiques de niveau recherche, publiés ou non, émanant des établissements d'enseignement et de recherche français ou étrangers, des laboratoires publics ou privés. 


\title{
A new cross-talk between Rap1 and Rac that regulates SAPPa secretion
}

\author{
Marjorie Maillet $^{1,4}$, Sylvain J. Robert ${ }^{1,3,4}$, Mathias Cacquevel ${ }^{5}$, Monique \\ Gastineau $^{1,4}$, Denis Vivien ${ }^{5}$, Jacques Bertoglio ${ }^{2,4}$, José L. Zugaza ${ }^{2,4, \#, *}$, Rodolphe \\ Fischmeister ${ }^{1,4}$ \& Frank Lezoualc' ${ }^{1,4, \pi}$ \\ ${ }^{1}$ Cardiologie Cellulaire et Moléculaire, INSERM U-446 \\ ${ }^{2}$ Récepteurs et Signalisation des Interleukines, INSERM U-461 \\ ${ }^{3}$ Neuropharmacologie, EA2707 \\ ${ }^{4}$ Institut de Signalisation et Innovation Thérapeutique (IFR 75); Université Paris-Sud, \\ Faculté de Pharmacie, F-92296 Châtenay-Malabry, France \\ ${ }^{5}$ UMR CNRS 6551, Centre Cyceron, IFR 47,14074 Caen Cedex, France \\ \#Present address: Centro de Investigación del Cáncer, Campus Miguel de Unamuno \\ 37007 Salamanca, Spain \\ *e-mail: jzugaza@usal.es \\ "e-mail: Frank.Lezoualch@cep.u-psud.fr
}




\begin{abstract}
Cyclic AMP (cAMP) production results from the activation of Gs protein-coupled receptors, and regulates many physiological processes through activation of protein kinase A (PKA). Here we report that a Rho GTPase, Rac, is regulated by cAMP in a PKA-independent manner. We also show that Rac activation results from activation of a Ras GTPase, Rap1, via the guanine-nucleotide exchange factor Epac1. Activation of the Gs-coupled 5-HT4 receptor initiates this signalling cascade. Finally, we demonstrate that this new cross-talk between Ras and Rho GTPase families is involved in the cAMPdependent processing of the amyloid precursor protein, indicating that this signalling pathway may serve important cellular functions.
\end{abstract}


Cyclic AMP is a second messenger which is produced in response to a large variety of extracellular signals and is involved in a wide range of cell-type specific effects, such as cell growth, cell differentiation, exocytosis and memory ${ }^{1,2}$. Classically, cAMP mediates its cellular effects through activation of the protein kinase A (PKA) which induces phosphorylation of cytoplasmic and nuclear proteins, including enzymes and transcription factors $^{3}$. However, a large body of evidence indicates that cAMP regulates a number of specific cellular functions through PKA-independent pathways. For instance, cAMP directly regulates some neuronal functions underlying neurotransmitter signalling and memory ${ }^{4,5}$. More recently, we have shown that activation of a canonical Gs-coupled-receptor, the serotonin $5-\mathrm{HT}_{4}$ receptor may influence the processing of a key protein implicated in Alzheimer's disease $(\mathrm{AD})^{6}$, the amyloid precursor protein (APP), through a mechanism involving cAMP production but not PKA activation ${ }^{7}$. The resulting effect of this PKAindependent stimulatory process is the secretion of the non-amyloidogenic soluble form of APP $(\operatorname{sAPP} \alpha)^{7}$. These findings suggest the existence of alternative pathways by which $G$ protein-coupled receptors (GPCRs) may regulate cell functions via cAMP.

Members of the Rho family of small GTPases are involved in the regulation of endocytotic pathways and have been shown to regulate secretory trafficking ${ }^{8-10}$. Therefore, we focused our research on small GTPase proteins as possible partners in the intracellular signalling pathway that couples the serotonin $5-\mathrm{HT}_{4}$ receptor to APP processing. We found that the $5-\mathrm{HT}_{4}$ receptor stimulates the activity of the small GTPase, Rac in a cAMP-dependent but PKAindependent manner. Furthermore, we provide experimental evidence that the cAMP regulated guanine nucleotide exchange factor (GEF), Epac1 ${ }^{11,12}$ regulates sAPP $\alpha$ secretion through Rap1, a small GTPase of the Ras family and Rac. These data reveal an unsuspected connection between two families of small GTPases, and imply that Rac can function downstream of cAMP/Epac1/Rap1 in a novel signal transduction secretory pathway. 


\section{Results}

\section{Recombinant and native 5-HT 4 receptors induce $\mathrm{SAPP} \alpha$ secretion and activate Rac.}

The amyloid $\beta$-protein $(A \beta)$ is one of the major component of the senile plaques in the brain of AD patients and derives from its precursor APP by the action of $\beta$ - and $\gamma$-secretases ${ }^{6}$. On the other hand, the $\alpha$-secretase pathway splits APP within the A $\beta$ domain producing a large amino-terminal non-amyloidogenic soluble APP ( $\mathrm{APP} \alpha)$, which is secreted in the extracellular medium and has neurotrophic activities and potent memory-enhancing effects $^{13,14}$. The effect of the activation of the $5-\mathrm{HT}_{4}$ receptor on SAPP $\alpha$ release was analysed in CHO cells stably expressing the neuronal human $5-\mathrm{HT}_{4(\mathrm{e})}$ receptor isoform $\left(\mathrm{h} 5-\mathrm{HT}_{4(\mathrm{e})}\right)^{15}$. Since endogenous levels of APP in non neuronal cell lines are relatively low, we stably transfected these CHO cells with the major isoform of the human neuronal APP, APP695. As previously reported on native rodent $\mathrm{APP}^{7}$, activation of the h5- $\mathrm{HT}_{4(\mathrm{e})}$ receptor by $1 \mu \mathrm{M} 5-\mathrm{HT}$ enhances secretion of human SAPP $\alpha$ (Fig. 1a). This process is independent of PKA since the PKA inhibitor, H89 $(10 \mu \mathrm{M})$ failed to block the stimulating effect of 5-HT on human sAPP $\alpha$ release (Fig. 1a). The regulation by the $5-\mathrm{HT}_{4}$ receptor of APP processing was not restricted to $\mathrm{CHO}$ cells, since it was also observed in primary culture of embryonic mouse cortical neurons (Fig. 1b \& c). Indeed, two selective 5-HT4 agonists, ML10302 and prucalopride ${ }^{16,17}$, enhanced sAPP $\alpha$ secretion in primary neurons maintained in culture for 14 days (Fig. 1b \& c). The stimulatory effect of $1 \mu \mathrm{M}$ ML10302 on sAPP $\alpha$ secretion was inhibited by the selective 5-HT 4 antagonist, GR113808 $(1 \mu \mathrm{M})$ in these neuronal cells (Fig. 1b). To examine the involvement of cAMP in APP metabolism, primary mouse cortical neurons were treated by the adenylyl cyclase activator forskolin (FSK, $10 \mu \mathrm{M}$ ) or a membrane permeant cAMP analogue adenosine 3',5' monophosphothioate (Rp-cAMPS, $10 \mu \mathrm{M}$ ) which does not activate $\mathrm{PKA}^{46}$ (Fig. 1c). Both drugs mimicked the effects of 5-HT4 ligands on sAPP $\alpha$ secretion 
indicating that cAMP but not PKA is involved in APP metabolism in primary cortical neurons (Fig. 1c). Among the Rho family of GTPases which includes Rho, Cdc42 and Rac, RhoA and Cdc42 have been shown to be regulated by cAMP in a PKA-dependent manner ${ }^{18-21}$. Therefore, we focused our interest on Rac and examined its potential involvement in the above PKA-independent effects of 5- $\mathrm{HT}_{4}$ receptor on APP processing.

We directly assayed Rac GTP-loading using a glutathione S-transferase (GST) fusion protein containing the Cdc42-Rac interactive binding domain (CRIB) of p21-activated kinase (PAK). When the GST-CRIB fusion protein coupled to glutathione beads was incubated with cell lysates from quiescent $\mathrm{CHO}$ cells that had been previously treated with $1 \mu \mathrm{M} 5$-HT for different periods of time, we found that 5-HT induced Rac activation (Fig. 2a). Increasing concentrations of 5-HT significantly enhanced Rac GTP-loading compared to untreated cells (Fig. 2b). As shown in Fig. 2c, $1 \mu \mathrm{M}$ of the selective 5-HT 4 receptor antagonist, GR113808, fully blocked 5-HT (1 $\mu \mathrm{M})$-enhanced Rac activation in $\mathrm{CHO}$ cells expressing the h5-HT $4(\mathrm{e})$ receptor indicating that the effect of 5-HT on Rac activation was indeed mediated by the h5$\mathrm{HT}_{4(\mathrm{e})}$ receptor. GR113808 $(1 \mu \mathrm{M})$ also reduced the basal level of Rac-GTP indicating a constitutive activity of the expressed h5-HT4(e) receptor (Fig. 2c). To test whether native 5$\mathrm{HT}_{4}$ receptors can also activated Rac, we repeated these experiments in primary mouse cortical neurons and in the human IMR32 neuroblastoma cell line. In both systems, the two selective $5-\mathrm{HT}_{4}$ agonists, prucalopride $(1 \mu \mathrm{M})$ and ML10302 (1 nM to $\left.1 \mu \mathrm{M}\right)$, induced a strong activation of Rac and their effects were inhibited by the selective $5-\mathrm{HT}_{4}$ antagonist, SB204070 $(1 \mu \mathrm{M})$ (Fig. 2d \& e). Furthermore, we observed that the increase in Rac activation upon treatment of the cells with the $5-\mathrm{HT}_{4}$ agonists was accompanied by an increase in the intracellular level of cAMP (data not shown). Altogether, these results demonstrate that recombinant and native 5- $\mathrm{HT}_{4}$ receptors specifically induce the conversion of Rac into an activated state. 
cAMP activates Rac. To examine the involvement of cAMP in Rac activity, CHO cells stably transfected with the h5-HT4(e) receptor isoform were treated with FSK $(10 \mu \mathrm{M})$ or the phosphodiesterase inhibitor isobutylmethylxanthine (IBMX, $100 \mu \mathrm{M}$ ) for $10 \mathrm{~min}$. The amount of Rac-GTP was determined as above (Fig. 3a). Both compounds mimicked the effects of 5HT since they caused a strong increase in the amount of Rac-GTP (Fig. 3a). The maximal amount of Rac-GTP was about 7-fold (range $5.6 \pm 1.9$ to $8 \pm 1.5$ ) above its basal level (Fig. 3a, lower panel). A 10 min exposure of $\mathrm{CHO}$ cells to cell-permeable cAMP analogues, 8bromo-cyclic AMP (8-Br-cAMP, $10 \mu \mathrm{M})$ or Rp-cAMPS $(10 \mu \mathrm{M})$, activated Rac to the same extent as did treatment with forskolin and IBMX (Fig. 3b). A similar effect of FSK (10 $\mu \mathrm{M})$, 8-Br-cAMP $(100 \mu \mathrm{M})$ or Rp-cAMPS $(10 \mu \mathrm{M})$ on Rac activation was found in IMR32 neuroblastoma cells (Fig. 3c) and primary cortical neurons (Fig. 3d).

cAMP regulates Rac activation in a PKA-independent manner. Functional consequences of a rise in cAMP upon activation of Gs protein-coupled receptors usually involves activation of PKA and phosphorylation of substrate proteins ${ }^{1,3}$. Thus, we examined whether the effects of the 5- $\mathrm{HT}_{4}$ receptor on Rac activation was PKA-dependent. First, CHO cells transfected with the $5-\mathrm{HT}_{4(\mathrm{e})}$ receptor were pre-treated with $5 \mu \mathrm{M}$ of the potent PKA inhibitor, H89, and Rac activation in response to 5-HT $(1 \mu \mathrm{M})$ or FSK $(10 \mu \mathrm{M})$ was measured by the affinity precipitation assay (Fig. $4 \mathrm{a} \& \mathrm{~b})$. Although H89 (5 $\mu \mathrm{M})$ completely abolished PKA activity (Fig. 4a \& b, lower panels), it failed to block 5-HT- or FSK-induced Rac activation (Fig. 4a, middle and upper panels and $4 \mathrm{~b}$, upper panel). These data are consistent with the results reported in Fig. 3b, c \& d. Indeed, the cAMP analogue and PKA inhibitor, Rp-cAMPS (10 $\mu \mathrm{M}$ ), greatly enhanced the amount of the GTP bound form of Rac in CHO and neuronal cells (Fig. 3). Second, in a mutant CHO 10260 cell line that has been characterized as exhibiting 
more than $95 \%$ reduction in both type I and II PKA activities ${ }^{23}$, FSK still induced Rac activation (Fig. 4c). The increase in the amount of Rac-GTP in CHO 10260 cells was not significantly different from that observed in the parental CHO 10001 cell line (Fig. 4c). In contrast, basal and stimulated levels of PKA activities were dramatically lower in the $\mathrm{CHO}$ mutants cells than in the parental cells (Fig. 4c lower panel right). We therefore conclude that Rac is activated by cAMP independently of PKA.

Epac1 and Rap1 are involved in cAMP-dependent Rac activation. Rho GTPases are activated by a family of GEFs known as Dbl family proteins. These proteins share tandem Dbl homology (DH) and pleckstrin homology (PH) domains. DH domain catalyses nucleotide exchange on Rho GTPases ${ }^{24}$. We have searched databases for GEFs containing both DH domain and cAMP-binding site but did not identify any sequence with the characteristics of a gene encoding such a protein. A family of GEFs that bind cAMP with affinities similar to that of the regulatory subunit of type I PKA and are directly activated by cAMP have been recently identified ${ }^{11,12}$. These proteins, called Epac or cAMP-GEFs, have been shown to function as exchange factors for Rap GTPases which belong to the Ras superfamily ${ }^{11}$. In particular, it has been clearly established that cAMP-dependent activation of Rap1 involves $\mathrm{Epac}^{25}$. Therefore, we searched for a potential involvement of Epac-Rap1 in 5-HT 4 receptordependent Rac activation. To do this, we first investigated the effects of an activation of the 5$\mathrm{HT}_{4}$ receptor on Rap1 activation. Pull down assays using GST-Ral-GDS-Rap1-binding domain showed that 5-HT was able to activate Rap1 in CHO cells stably expressing the 5$\mathrm{HT}_{4(\mathrm{e})}$ receptor (Fig. 5a). Interestingly, the PKA inhibitor and cAMP analogue, Rp-cAMPS efficiently activated Rap1 (Fig. 5a). 5-HT-induced Rap1 activation was blocked by the selective 5- $\mathrm{HT}_{4}$ antagonist SB204070 indicating that the reaction specifically involved the 5$\mathrm{HT}_{4(\mathrm{e})}$ receptor (Fig. 5a). 5- $\mathrm{HT}_{4}$ receptor activation also enhanced Rap1 activation in primary 
neuronal culture (data not shown) and in IMR32 neuroblastoma cells (see supplemental data, S1 Fig. 1). Thus, we conclude that Rap1 is involved in the $5-\mathrm{HT}_{4}$ receptor signalling pathway.

Next, we examined the involvement of Epac1 in this process. To do this, we transiently transfected $\mathrm{CHO}$ cells with a plasmid encoding a mutated form of Epac1 (Epac- $\Delta \mathrm{cAMP}$ ) which lacks the cAMP-binding domain ${ }^{11}$. Epac- $\Delta$ cAMP therefore behaves as a constitutive activated form of Epac1 and cannot be regulated by cAMP ${ }^{25}$. Transfection of Epac- $\Delta$ cAMP induced Rac activation in a concentration dependent manner (Fig. 5b). Furthermore, a novel Epac-specific cAMP analogue which does not activate PKA, 8CPT-2Me-cAMP ${ }^{26}$ also increased Rac activation in CHO and IMR32 cells transiently transfected with Epac1 (Fig. 5c). This compound also induced Rac activation in cells non transfected with Epac1 such as primary neurons (Fig. 5c) and CHO cells (data not shown). Similarly, CHO cells transfection with a positive dominant form of Rap1 (Q63E-Rap1) strongly increased the amount of Rac GTP (Fig. 5d). Transfection of Epac- $\Delta$ cAMP or Q63E-Rap1 also enhanced Rac activation in IMR32 cells (see supplemental data, S1 Fig. 1). In a similar approach, we examined the effects of a functional inactive form of Epac ( $\Delta 1$-148Epac), in which the first 148 amino acid residues have been removed thereby preventing its proper cellular localisation ${ }^{27}$, or a Rap1 GTPase activating protein (RapGAP) which strongly lowers the level of Rap1-GTP. $\Delta 1$ 148Epac or RapGAP were co-transfected into CHO cells with Rac1 and their effects on the activation of transfected tagged Rac were determined by pull down experiments. As shown in Fig. 5e and 5f, cell transfection with $\Delta$ 1-148Epac or RapGAP strongly inhibited 5-HTinduced Rac activation. The stimulatory effect of FSK on Rac activation was also blocked by these dominant negative constructs in $\mathrm{CHO}$ cells (data not shown). Since Ras has also been shown to be activated by cAMP independently of $\mathrm{PKA}^{28}$, we performed Rac pull down experiments upon cotransfection of Rac1 and a negative dominant form of Ras (RasN17). Transfected RasN17 did not influence the effect of the 5-HT 4 receptor on Rac activation 
indicating that cAMP-induced Rac activation is independent of Ras (Fig. 5g). Altogether, these data clearly indicate that cAMP-dependent Rac activation is mediated by Epac1 and Rap1.

Involvement of Rac in the h5-HT4(e) receptor induced-sAPP $\alpha$ secretion. To further validate this new signalling pathway, we analysed its possible involvement in sAPP $\alpha$ secretion. Transfection of constitutive active Epac- $\Delta \mathrm{cAMP}$ in $\mathrm{CHO}$ cells increased the cellular release of sAPP $\alpha$ in the absence of stimulation and rendered it independent of 5HT (Fig. 6a). Furthermore, 8CPT-2Me-cAMP also increased sAPP $\alpha$ secretion in CHO and IMR32 cells transfected with Epac1 (Fig. 6b). Activation of endogenous Epac with 8CPT2Me-cAMP also increased sAPP $\alpha$ secretion in primary neurons and IMR32 neuroblastoma cells (Fig. 6b and supplemental data, S1 Fig. 1c). Consistent with this result, Q63E-Rap1 enhanced basal secretion of sAPP $\alpha$ whereas functional inactive form of Epac, $\Delta 1$-148Epac, and RapGAP inhibited 5-HT-induced cellular release of sAPP $\alpha$ (Fig. 6c \& d). Similar results were observed in IMR32 cells (see supplemental data, S1 Fig. 1). Finally, a dominant negative Rac (N17Rac) inhibited basal and 5-HT-induced cAMP-dependent secretion of sAPP $\alpha$ when transfected in $\mathrm{CHO}$ cells (Fig. 6e). In contrast, constitutive activated form of Rac (V12Rac) mimicked the stimulating effect of 5-HT on sAPP $\alpha$ secretion in the absence of 5-HT 4 ligand (Fig. 6e). Transfected dominant negative and positive forms of Rac were effective in our system since they decreased and enhanced Rac activation, respectively (Fig. 6e). The lesser increase in Rac activation observed in control cells stimulated with 5-HT was due to the longer incubation period with the neurohormone. We indeed noticed that upon 30 min treatment with $1 \mu \mathrm{M}$ 5-HT Rac activation decreased compared to the short period of 
activation (data not shown). Altogether, our results indicate that this novel signalling pathway involving Epac1, Rap1 and Rac is implicated in APP processing.

\section{Discussion}

On the basis of our observations, we propose a new signalling pathway (Fig. 7), initiated at a GPCR positively coupled to adenylyl cyclase (AC), in which Rac is activated by Rap1 following cAMP binding to Epac1. In the case of the h5-HT 4 receptor this novel cAMPdependent, PKA-independent signalling pathway is involved in APP processing. Serotonin 5$\mathrm{HT}_{4}$ receptors are distributed in a variety of mammalian tissues including brain, heart and digestive system, where they mediate many physiological effects of 5-HT. In addition, 5-HT4 receptors are thought to be involved in various pathological conditions, such as atrial arrhythmia and neurodegenerative disease ${ }^{29}$. Our results thus open new insights into the signalling pathways by which $5-\mathrm{HT}$ through the $5-\mathrm{HT}_{4}$ receptor may mediate its biological

effects. Besides its role in APP metabolism, this finding suggests that activation of the $5-\mathrm{HT}_{4}$ receptor may also influence cytoskeletal dynamic. Accordingly, activation of the recombinant $\mathrm{h} 5-\mathrm{HT}_{4(\mathrm{a})}$ receptor isoform in a murine neuronal cell line promotes RhoA-dependent neurite retraction ${ }^{30}$.

In our study, we found that forskolin and three cAMP analogues, 8-Br-cAMP, Rp-cAMPS and $8 \mathrm{CPT}-2 \mathrm{Me}-\mathrm{cAMP}$ mimicked the activation of Rac by the $5-\mathrm{HT}_{4}$ receptor. This indicates a cross talk between cAMP and Rac and is in agreement with a recent report showing that another GPCR positively linked to the heterotrimeric protein Gs, the adenosine $A_{2}$ receptor, activates the small GTPase Cdc42 by a mechanism involving cAMP ${ }^{21}$. In most cellular systems, cAMP effects have been associated with the activation of PKA. For instance, PKA phosphorylation of the GTP binding protein RhoA was reported to be a central event in mediating the morphological effects of cAMP in cytotoxic lymphocytes ${ }^{18}$. PKA has also been 
recently involved in cAMP-dependent Cdc42 activation $^{21}$. Here we showed that Rac activation is induced by cAMP in a PKA-independent manner in $\mathrm{CHO}$ and neuronal cells suggesting an alternative mode of cAMP action. The stimulating and inhibiting effects of dominant positive and negative forms of Epac on Rac activation, respectively, indicated that Epac is involved in this signalling pathway. In contrast to our study, Rac activation by chemoattractants, $\beta 1$ integrins and prostaglandin E2 requires PKA activity in MDA-MB-435 human breast cancer carcinoma cells and in human umbilical vein endothelial cells ${ }^{31,32}$. As Rac does not contain any consensus PKA phosphorylation sites, it is suggested that PKA may regulate Rac indirectly via the phosphorylation of its specific GEFs such as Tiam-1 and Trio $^{31}$. Therefore, depending on the level of expression of the GEF in a given cell, the effects of cAMP on Rac may be mediated by PKA-dependent or PKA-independent mechanisms.

Several studies have shown that Ras and Rho GTPases can be activated in cascade so that one small GTPase stimulates GTP loading on another one ${ }^{33}$. For instance, Cdc42 has been shown to activate Rac in different cellular systems and Rac may downregulate or upregulate Rho activity ${ }^{34,35}$. With respect to the Ras superfamily, Rap1 antagonizes Ras-induced activation of mitogenesis ${ }^{36}$. Cross-talk can also occur between the two families of GTPases and, for instance, in neuroblastoma cells Ras-induced outgrowth is mediated by both Cdc42 and Rac activity ${ }^{37}$. Our report is the first to show a cross-talk between Rap1 and Rac that involves the second messenger cAMP.

Interestingly, we found that the cAMP analogue and PKA inhibitor, Rp-cAMPS not only activated Rac but also strongly enhanced Rap1 activity in our cellular systems. Likewise, RpcAMPS also enhanced sAPP $\alpha$ release. In accordance with our results, Rp-cAMPS was shown to mimic the stimulating effect of calcitonin on $\mathrm{H}, \mathrm{K}-\mathrm{ATP}$ ase in collecting duct cells, a process which is entirely dependent of Epac and Rap ${ }^{47}$. However, Rehmann and colleagues ${ }^{48}$ have recently mentioned in their study the unpublished observation that Rp-cAMPS binds to but 
does not activate Epac. Clearly, if this finding is confirmed in vitro and in vivo, a question arises on how Rp-cAMPS may activate Rap1? We propose that Rp-cAMPS may act indirectly, by increasing the intracellular pool of cAMP available for Epac activation. This could be done two ways: Rp-cAMPS, which is hydrolysis-resistant, may bind to but not activate cAMP phosphodiesterases (PDE), which might result in PDE inhibition and cAMP accumulation. In support of this hypothesis, Sp-cAMPS, another cAMP analogue related to Rp-cAMPS, functions as a competitive inhibitor of PDE3A ${ }^{49}$. Alternatively, Rp-cAMPS, which inhibits PKA, might relieve an inhibitory effect of PKA on adenylyl cyclase ${ }^{50}$ and/or alleviate the stimulatory effect of PKA on PDE3 ${ }^{50}$ and PDE4 ${ }^{50-55}$ activities. Such a direct or indirect inhibitory effect of Rp-cAMPS on PDE could lead to comparable effects as those of IBMX (Fig. 3a).

Rap1 has been implicated in various biological processes such as cell differentiation and integrin-mediated cell adhesion ${ }^{38}$. Interestingly, Rap1 may be associated with secretory vesicles and play a role in the regulation of secretion ${ }^{39}$. In favour of this hypothesis, cAMPGEFII (also called Epac2) which regulates Rap1 activity ${ }^{25}$ is responsible for cAMP-dependent and PKA-independent exocytosis, particularly the $\mathrm{Ca}^{2+}$-dependent secretion of growth hormone ${ }^{40}$. Members of the Rho family have also been shown to regulate exocytosis. Indeed, Cdc42 and Rac regulate secreting processes in different cell types such as neurones and mast cells ${ }^{9,10}$. Here, we show for the first time that Rac is implicated in a precise cellular function which involves the 5-HT4 receptor and APP metabolism. Rap1 activity is required in this process. It is unclear at the moment whether the effects of the small GTPases, Rap1 and Rac on APP metabolism are directly linked to an increase in the activity of the $\alpha$-secretases or an effect on cellular trafficking of APP. Given the involvement of Rap1 and Rac in the regulation of secretory processes, it is reasonable to think that these GTPases may target APP to cellular compartments involved in $\alpha$-secretase processing or are directly involved in the 
secretion of sAPP $\alpha$ at the cell surface. Recent experiments performed in yeast supports such a connection between Rap1, Rho GTPases and secretory processes. Bud1 is the yeast homologue of Rap1 and interacts and activates Cdc24p, a GEF for the Rho-family GTPase. In Saccharomyces cerevisiae, Cdc24p activates $\mathrm{Cdc} 42$ which recruits a number of effectors to the budding site allowing polarization of the actin cytoskeleton and targeting secretion to that site $^{41,42}$. Further investigation is needed to test whether Rap1 GTPases may recruit and activate a specific Rho GEF which would switch on Rac in mammalian cells. Alternatively, a possible connection between Rap1 and Rac could involve integrins. Indeed, integrins induce local Rac effector coupling by targeting Rac to membranes and leading to the dissociation of Rho guanine nucleotide dissociation inhibitors ${ }^{43}$. This observation combined with the recent data that Rap1A activates integrins may suggest that these molecules may be involved in cAMP dependent Rap-Rac activation ${ }^{44}$.

In summary, we show here that Rac is regulated in a cAMP-dependent but PKAindependent manner through Epac1 and Rap1. The identification of Rap1 and Rac as two elements in a signalling pathway controlling a cAMP-dependent secretory process provides the molecular basis for a new cross-talk between Ras GTPases and Rho GTPases. 


\section{Methods}

\section{Reagents, cell culture and transfection}

All media, sera, and antibiotics used in the cell culture were purchased from Life Technologies (Cergy Pontoise, France). GR113808, GR127935, SB204070 were gifts from Glaxo SmithKline Beecham (Harlow, UK). ML10302 and prucalopride were generously given by Sames Sicsic (BIOCIS UPRES A CNRS 8076, Châtenay-Malabry, France) and Janssen Research Foundation (Beerse, Belgium), respectively. 5-HT and IBMX were from Sigma Aldrich (L'Isle d'Abeau Chesmes, France). Forskolin, 8-Br-cAMP, Rp-cAMPS and H89 were purchased from Calbiochem (France Biochem, Meudon, France). 8-(4-chlorophenylthio)-2'-O-methyladenosine-3'-5'-cyclic monophosphate (8CPT-2Me-cAMP) was from Biolog Life Science Institute (Bremen, Germany). Pure neuronal cultures of mice containing less than $5 \%$ astrocytes were prepared as previously described ${ }^{45}$. Dissociated cortical cells in MEM medium supplemented with 5\% foetal bovine and 5\% horse serum were plated in multiwell vessels that had been previously coated with poly-D-lysine and laminin and $10 \mu \mathrm{M}$ cytosine arabinoside was added after 3 days in vitro. At 12 days in vitro, neuronal culture was switched to serum free condition to avoid any presence of 5-HT in the culture medium provided by the serum. Experiments were performed after 14-15 days in vitro in serum free medium. CHO and IMR32 cells were grown respectively in HamF12 and MEM media with $10 \%$ FCS and antibiotics. Before any treatment, IMR32 cells and CHO cells were serum starved for $48 \mathrm{~h}$. In $\mathrm{CHO}$ cells stably expressing the h5-HT4(e) receptor, $1 \mu \mathrm{M}$ GR127935 was used to block the endogenous 5-HT $\mathrm{H}_{1(\mathrm{~b})}$ receptors. Transient transfection experiments were performed with jetPEI ${ }^{\mathrm{TM}}$ (Polyplus-transfection, Illkirch, France) according to the manufacturer instructions. Expression of transfected proteins was determined by immunoblotting with anti-Flag, anti-HA or anti-GFP antibodies. 


\section{Rap and Rac activation assay}

Rap1 pull down experiments were exactly performed as previously described using the GST fusion protein containing the Rap1-binding domain of Ral-GDS ${ }^{11}$. Rac activation was measured as follows. After stimulation, cells were lysed in RIPA buffer (50 mM Tris pH 7.5, $500 \mathrm{mM} \mathrm{NaCl}, 20 \mathrm{mM} \mathrm{MgCl} 2,0.5 \%$ deoxycholic acid, 0.1\% SDS, 1\% Triton X100, $1 \mathrm{mM}$ PMSF, $10 \mu \mathrm{g} / \mathrm{ml}$ leupeptin and aprotinin) and clarified by centrifugation at $15000 \mathrm{~g}$ at $4^{\circ} \mathrm{C}$ for 20 min. Protein concentration was determined by BCA assay (Sigma Aldrich, L'Isle d'Abeau Chesnes, France). Two $\mathrm{mg}$ of proteins (1 $\mathrm{mg}$ for transient transfection) were incubated with $50 \mu \mathrm{g}$ GST-CRIB of PAK coupled to gluthatione sepharose beads for 1 hour at $4^{\circ} \mathrm{C}$. The beads were then washed 3 times in washing buffer $(50 \mathrm{mM}$ Tris $\mathrm{pH} 7.5,150 \mathrm{mM} \mathrm{NaCl}, 20$ $\mathrm{mM} \mathrm{MgCl} 2,1 \%$ Triton X-100, $0.1 \mathrm{mM}$ PMSF, $10 \mu \mathrm{g} / \mathrm{ml}$ leupeptin and aprotinin) and protein extracted in Laemmli's buffer. Rac-GTP samples and total lysates $(40 \mu \mathrm{g})$ were separated in a 15\% SDS-PAGE and transfered onto a polyvinylidene difluoride (PVDF) membrane (Hybond-P, Amersham Pharmacia Biotech, Saclay, France). Membranes were hybridized with an anti-Rac monoclonal antibody (a gift from Toshifumi Azuma) and proteins were visualized by enhanced chemiluminescence $\left(\mathrm{ECL}^{+}\right.$, Amersham Pharmacia Biotech, Saclay, France). Densitometric analysis was performed using a Biorad image acquisition system (Ivry-Sur-Seine, France, gel doc 1000) and fold induction of Rac activation compared to control was calculated.

\section{In vitro kinase reactions and cAMP assays.}

Protein kinase A activity and cAMP assays were exactly performed as previously described ${ }^{7,28}$.

\section{Measurement of sAPP $\alpha$.}


CHO cells expressing the h5-HT4(e) receptor were stably transfected with APP695. Confluent $\mathrm{CHO}$ cells were cultured in $10 \%$ dialysed FCS-containing medium overnight. After drug treatment in serum free medium, media were centrifuged and concentrated by ultrafiltration (Vivaspin columns, Vivascience, Palaiseau, France). sAPP $\alpha$ was detected as previously described $^{7}$ by Western blotting using the monoclonal antibody 6E10 (Signet pathology systems, Dedham, USA) or the rabbit polyclonal antiserum R1736 (provided by Dr Selkoe, Harvard Medical School, Boston) which are selective of the $\alpha$ secreted cleavage of APP.

\section{Statistical analysis.}

An unpaired Student's $t$-test was used to calculate differences between means; differences were considered significant when $p$ was at least $<0.05$. 


\section{ACKNOWLEDGEMENTS}

We wish to thank Michael Gottesman, Johannes Bos, Xiaodong Cheng, Jean de Gunsburg for providing CHO 10001/10260, Epac1 and Rap plasmid constructs. The cDNA encoding the human APP695 was kindly provided by Christian Haass. We thank Pascal Bochet for help in database search, and Jacqueline Bréard, Georges Gaudriault, Jean de Gunsburg and Saadia Kerdine for helpful advice and critical reading of the manuscript. JLZ has a contract in the Ramón y Cajal Programme from the Spanish Ministry of Science and Technology. 


\section{References}

1. Meinkoth, J.L. et al. Signal transduction through the cAMP-dependent protein kinase. Mol. Cell. Biochem. 127-128, 179-186 (1993).

2. Larkman, A.U. \& Jack, J.J. Synaptic plasticity: hippocampal LTP. Curr. Opin. Neurobiol. 5, 324-334 (1995).

3. Montminy, M. Transcriptional regulation by cyclic AMP. Annu. Rev. Biochem. 66, 807-822 (1997).

4. Huang, Y.Y. et al. A genetic test of the effects of mutations in PKA on mossy fiber LTP and its relation to spatial and contextual learning. Cell 83, 1211-1222 (1995).

5. Brandon, E.P., Idzerda, R.L. \& McKnight, G.S. PKA isoforms, neural pathways, and behaviour: making the connection. Curr. Opin. Neurobiol. 7, 397-403 (1997).

6. Selkoe, D.J. Translating cell biology into therapeutic advances in Alzheimer's disease. Nature 399, A23-A31 (1999).

7. Robert, S.J., Zugaza, J.L., Fischmeister, R., Gardier, A.M. \& Lezoualc'h, F. The human serotonin 5-HT 4 receptor regulates secretion of non-amyloidogenic precursor protein. J. Biol. Chem. 276, 44881-44888 (2001).

8. Kroschewski, R., Hall, A. \& Mellman, I. Cdc42 controls secretory and endocytic transport to the basolateral plasma membrane of MDCK cells. Nat. Cell. Biol. 1, 8-13 (1999).

9. Doussau, F. et al. A Rho-related GTPase is involved in $\mathrm{Ca}(2+)$-dependent neurotransmitter exocytosis. J. Biol. Chem. 275, 7764-7770 (2000).

10. Hong-Geller, E. \& Cerione, R.A. Cdc42 and Rac stimulate exocytosis of secretory granules by activating the $\mathrm{IP}_{3} /$ calcium pathway in RBL-2H3 mast cells. J. Cell. Biol. 148, 481-494 (2000).

11. de Rooij, J. et al. Epac is a Rap1 guanine-nucleotide-exchange factor directly activated by cyclic AMP. Nature 396, 474-477 (1998).

12. Kawasaki, H. et al. A family of cAMP-binding proteins that directly activate Rap1. Science 282, 2275-2279 (1998).

13. Mattson, M.P. et al. Evidence for excitoprotective and intraneuronal calcium-regulating roles for secreted forms of the $\beta$-amyloid precursor protein. Neuron. 10, 243-254 (1993). 
14. Meziane, H. et al. Memory-enhancing effects of secreted forms of the $\beta$-amyloid precursor protein in normal and amnesic mice. Proc. Natl. Acad. Sci. U S A. 95, 12683-12688 (1998).

15. Mialet, J. et al. Isolation of the serotoninergic 5-HT4(e) receptor from human heart and comparative analysis of its pharmacological profile in C6-glial and $\mathrm{CHO}$ cell lines. $\mathrm{Br} . \mathrm{J}$. Pharmacol. 129, 771-781 (2000).

16. Langlois, M. et al. Design of a potent $5-\mathrm{HT}_{4}$ receptor agonist with nanomolar affinity. BioMed. Chem. Lett. 4, 1433-1436 (1994).

17. Briejer, M.R. et al. The in vitro pharmacological profile of prucalopride, a novel enterokinetic compound. Eur. J. Pharmacol. 423, 71-83 (2001).

18. Lang, P. et al. Protein kinase A phosphorylation of RhoA mediates the morphological and functional effects of cyclic AMP in cytotoxic lymphocytes. EMBO J. 15, 510-519 (1996).

19. Laudanna, C., Campbell, J.J. \& Butcher, E.C. Elevation of intracellular cAMP inhibits RhoA activation and integrin- dependent leukocyte adhesion induced by chemoattractants. $J$. Biol. Chem. 272, 24141-24144 (1997).

20. Dong, J.M., Leung, T., Manser, E., \& Lim, L. cAMP-induced morphological changes are counteracted by the activated RhoA small GTPase and the Rho kinase ROKalpha. J. Biol. Chem. 273, 22554-22562 (1998).

21. Feoktistov, I., Goldstein, A.E. \& Biaggioni, I. Cyclic AMP and protein kinase A stimulate cdc42: role of $\mathrm{A}_{2}$ adenosine receptors in human mast cells. Mol. Pharmacol. 58, 903-910 (2000).

22. Dumuis, A., Sebben, M. \& Bockaert, J. Pharmacology of 5-hydroxytryptamine-1A receptors which inhibit cAMP production in hippocampal and cortical neurons in primary culture. Mol. Pharmacol. 33, 178-186 (1988).

23. Gottesman, M.M., LeCam, A., Bukowski, M. \& Pastan, I. Isolation of multiple classes of mutants of CHO cells resistant to cyclic AMP. Somatic. Cell. Genet. 6, 45-61 (1980).

24. Kjoller, L. \& Hall, A. Signaling to Rho GTPases. Exp. Cell. Res. 253, 166-179 (1999).

25. de Rooij, J. et al. Mechanism of regulation of the Epac family of cAMP-dependent RapGEFs. J. Biol. Chem. 275, 20829-20836 (2000).

26. Enserink, J.M. et al. A novel Epac-specific cAMP analogue demonstrates independent regulation of Rap1 and ERK. Nat. Cell. Biol. 4, 901-906 (2002).

27. Mei, F.C. et al. Differential signaling of cyclic AMP: opposing effects of exchange protein directly activated by cyclic AMP and cAMP-dependent protein kinase on protein 
kinase B activation. J. Biol. Chem. 277, 11497-504 (2002).

28. Busca, R. et al. Ras mediates the cAMP-dependent activation of extracellular signalregulated kinases (ERKs) in melanocytes. EMBO J. 19, 2900-2910 (2000).

29. Hegde, S.S. \& Eglen, R.M. Peripheral 5-HT4 receptors. FASEB J. 10, 1398-1407 (1996).

30. Ponimaskin, E.G., Profirovic, J., Vaiskunaite, R., Richter, D.W. \& Voyno-Yasenetskaya, T.A. 5-hydroxytryptamine 4 a receptor is coupled to $\mathrm{G} \alpha$ subunit of heterotrimeric $\mathrm{G} 13$ protein. J. Biol. Chem. 277, 20812-20819 (2002).

31. O'Connor, K.L. \& Mercurio, A.M. Protein kinase A regulates Rac and is required for the growth factor-stimulated migration of carcinoma cells. J. Biol. Chem. 276, 47895-47900 (2001).

32. Dormond, O., Bezzi, M., Mariotti, A. \& Ruegg C. Prostaglandin E2 Promotes Integrin alpha Vbeta 3-dependent Endothelial Cell Adhesion, Rac-activation, and Spreading through cAMP/PKA-dependent Signaling. J. Biol. Chem. 277, 45838-45846 (2002).

33. Bar-Sagi, D. \& Hall, A. Ras and Rho GTPases: a family reunion. Cell 103, 227-238 (2000).

34. Ridley, A. J., Paterson, H. F., Johnston, C. L., Diekmann, D. \& Hall, A. The small GTPbinding protein rac regulates growth factor-induced membrane ruffling. Cell. 70, 401-10 (1992).

35. Sander, E.E., ten Klooster, J.P., van Delft, S., van der Kammen, R.A. \& Collard, J.G. Rac downregulates Rho activity: reciprocal balance between both GTPases determines cellular morphology and migratory behavior. J. Cell. Biol. 147, 1009-1022 (1999).

36. Schmitt, J.M. \& Stork, P.J. Cyclic AMP-mediated inhibition of cell growth requires the small G protein Rap1. Mol. Cell. Biol. 21, 3671-3683 (2001).

37. Sarner, S., Kozma, R., Ahmed, S. \& Lim, L. Phosphatidylinositol 3-kinase, Cdc42, and Rac1 act downstream of Ras in integrin-dependent neurite outgrowth in N1E-115 neuroblastoma cells. Mol. Cell. Biol. 20, 158-172 (2000).

38. Bos, J.L., de Rooij, J. \& Reedquist, K.A. Rap1 signalling: adhering to new models. Nat Rev Mol Cell Biol. 2, 369-377 (2001).

39. D'Silva, N.J., DiJulio, D.H., Belton, C.M., Jacobson, K.L. \& Watson, E.L. Immunolocalization of rap1 in the rat parotid gland: detection on secretory granule membranes. J. Histochem. Cytochem. 45, 965-973 (1997).

40. Ozaki, N. et al. cAMP-GEFII is a direct target of cAMP in regulated exocytosis. Nat. Cell. Biol. 2, 805-811 (2000). 
41. Pruyne, D. \& Bretscher, A. Polarization of cell growth in yeast. J. Cell. Sci. 113, 571-585 (2000).

42. Gulli, M.P. \& Peter, M. Temporal and spatial regulation of Rho-type guanine-nucleotide exchange factors: the yeast perspective. Genes Dev. 15, 365-379 (2001).

43. Del Pozo, M.A, et al. Integrins regulate GTP-Rac localized effector interactions through dissociation of Rho-GDI. Nat. Cell. Biol. 4, 232-239 (2002).

44. Sebzda, E. et al. Rap1A positively regulates $\mathrm{T}$ cells via integrin activation rather than inhibiting lymphocyte signaling. Nat. Immunol. 3, 251-258 (2002).

45. Koh, J.Y. \& Choi, D.W. Quantitative determination of glutamate mediated cortical neuronal injury in cell culture by lactate dehydrogenase efflux assay. J. Neurosci. Meth. 20, 83-90 (1987).

46. Rothermel, J.D. \& Parker Botelho, L.H. A mechanistic and kinetic analysis of the interactions of the diastereoisomers of adenosine 3',5'-(cyclic)phosphorothioate with purified cyclic AMP-dependent protein kinase. Biochem. J. 251, 757-762 (1988).

47. Laroche-Joubert, N., Marsy, S., Michelet, S., Imbert-Teboul, M. \& Doucet A. Protein kinase A-independent activation of ERK and H,K-ATPase by cAMP in native kidney cells: role of Epac I. J. Biol. Chem. 277, 18598-18604 (2002).

48. Rehmann, H. et al.. Structure and regulation of the cAMP-binding domains of Epac2. Nat. Struct. Biol. 10, 26-32 (2003).

49. Hung, S.H. et al. A new nonhydrolyzable reactive cAMP analog, (Sp)-adenosine-3',5'cyclic-S-(4-bromo-2,3-dioxobutyl)monophosphorothioate irreversibly inactivates human platelet cGMP-inhibited cAMP phosphodiesterase. Bioorg. Chem. 30,16-31 (2002).

50. Murthy, K.S., Zhou, H. \& Makhlouf, G.M. PKA-dependent activation of PDE3A and PDE4 and inhibition of adenylyl cyclase V/VI in smooth muscle. Am. J. Physiol. 282, C508517 (2002).

51. Sette, C. \& Conti, M. Phosphorylation and activation of a cAMP-specific phosphodiesterase by the cAMP-dependent protein kinase - Involvement of serine 54 in the enzyme activation. J. Biol. Chem. 271, 16526-16534 (1996).

52. Liu, H. G. \& Maurice, D. H. Phosphorylation-mediated activation and translocation of the cyclic AMP-specific phosphodiesterase PDE4D3 by cyclic AMP-dependent protein kinase and mitogen-activated protein kinases - A potential mechanism allowing for the coordinated regulation of PDE4D activity and targeting. J. Biol. Chem. 274, 10557-10565 (1999).

53. MacKenzie, S. J. et al. Long PDE4 cAMP specific phosphodiesterases are activated by protein kinase A-mediated phosphorylation of a single serine residue in Upstream Conserved Region 1 (UCR1). Br. J. Pharmacol. 136, 421-433 (2002). 
54. Manganiello, V. Short-term regulation of PDE4 activity. Br. J. Pharmacol. 136, 339-340 (2002).

55. Laliberte, F. et al. In vitro PKA phosphorylation-mediated human PDE4A4 activation. FEBS Lett. 512, 205-208 (2002). 


\section{Figure Legends}

Figure 1. The h5-HT4 receptor and cAMP regulate APP processing in $\mathrm{CHO}$ and primary neuronal cultures. a, 5-HT $(1 \mu \mathrm{M})$ increased sAPP $\alpha$ secretion in a PKAindependent manner in $\mathrm{CHO}$ cells. A representative immunoblot is shown. The cDNA coding for the human APP695 was stably cotransfected with the h5-HT4(e) receptor. Stable cell clones were selected for their ability to bind 5- $\mathrm{HT}_{4}$ ligands, stimulate cAMP production and regulate sAPP $\alpha$ secretion. H89 $(10 \mu \mathrm{M})$ was preincubated $10 \mathrm{~min}$ before the $30 \mathrm{~min}$ treatment with 1 $\mu \mathrm{M}$ 5-HT. Immunoblots were performed with the monoclonal $6 \mathrm{E} 10$ antibody which is selective of sAPP $\alpha . \mathbf{b}$, Selective 5-HT 4 ligands regulate sAPP $\alpha$ secretion in primary neuronal cultures. Primary cortical neurons from 14 days in vitro were incubated overnight with $1 \mu \mathrm{M}$ of the selective 5- $\mathrm{HT}_{4}$ agonist, ML10302 in the absence or presence of $1 \mu \mathrm{M}$ of the $5-\mathrm{HT}_{4}$ antagonist, GR113808. sAPP $\alpha$ was detected in the culture medium by immunoblotting using the R1736 antiserum. The lower panel shows the quantification of the signal which was expressed as fold activation of the control untreated cells in the same experiment. Results are means \pm S.E.M. for 3 independent experiments. $\mathrm{p}<0.01$, compared with untreated control cells, GR113808 or ML10302+GR113808 (t-test). c, sAPP $\alpha$ secretion is increased by cAMP in primary neurons. Mouse embryonic cortical neurons maintained in culture for 14 days were stimulated with the selective $5-\mathrm{HT}_{4}$ agonist, prucalopride $(1 \mu \mathrm{M})$, FSK $(10 \mu \mathrm{M})$ or with RpcAMPS $(10 \mu \mathrm{M})$ overnight. sAPP $\alpha$ secretion was determined as described in b. A $110 \mathrm{kDa}$ molecular weight marker is indicated at the left. CT, control cells.

Figure 2. The 5-HT4 receptor induces Rac activation. a, Time-dependent stimulation of Rac by $1 \mu \mathrm{M} 5$-HT in CHO cells stably expressing the $\mathrm{h} 5-\mathrm{HT}_{4(\mathrm{e})}$. Rac activation was analysed by pull down experiments using the GST-CRIB fusion protein. Precipitated proteins were 
subjected to Western blot using a monoclonal antibody to Rac. b, CHO cells expressing the h5-HT4(e) receptor isoform were incubated with increasing concentrations of 5-HT for $10 \mathrm{~min}$ and the amount of Rac-GTP was determined as in b. c, The specificity of the reaction was determined with the selective 5-HT4 receptor antagonist GR113808 $(1 \mu \mathrm{M})$, used in the presence of $1 \mu \mathrm{M}$ 5-HT. d, Selective 5-HT 4 ligands regulate Rac activation in primary cortical neurons. Cells were treated with a 5- $\mathrm{HT}_{4}$ agonist, prucalopride $(1 \mu \mathrm{M})$ for $10 \mathrm{~min}$, in the absence or presence of the 5-HT 4 antagonist, SB204070 $(1 \mu \mathrm{M})$. Cells were then lysed and assayed for GTP-bound Rac. e, The left panel shows a concentration-dependent stimulation of Rac by the selective 5-HT 4 agonist, ML10302 in IMR32 neuroblastoma cells. Right panel, the selective 5-HT 4 antagonist, SB204070 $(1 \mu \mathrm{M})$ inhibited ML10302 (1 $\mu \mathrm{M}, 5$ min)-induced Rac activation in IMR32 cells.

Figure 3. cAMP-dependent activation of Rac. a, b, CHO cells expressing the 5-HT4(e) receptor were treated with 5-HT $(1 \mu \mathrm{M})$, forskolin (FSK) $(10 \mu \mathrm{M})$, IMBX $(100 \mu \mathrm{M}), 8$-BrcAMP $(10 \mu \mathrm{M})$ or Rp-cAMPS $(10 \mu \mathrm{M})$ for $10 \mathrm{~min}$ and the amount of Rac-GTP was determined by pull down experiments and Western blot using an anti-Rac antibody. Lower panels, Rac-GTP is expressed as fold activation of the control (CT) cells (means \pm s.e.m; $n=4$ to 9). c, d, IMR32 cells and primary cortical neurons were treated and analysed for Rac activation as in (a) and (b). Prucalopride was used at a final concentration of $1 \mu \mathrm{M}$. CT, control untreated cells. $\mathrm{p}<0.05, \mathrm{p}<0.01$ compared with control cells (Student $t$-test).

Figure 4. 5-HT 4 receptor- and forskolin-induced Rac activation is independent of PKA. a, b, CHO cells were preincubated for 15 min with the PKA inhibitor H89 $(5 \mu \mathrm{M})$ and stimulated with 5-HT $(1 \mu \mathrm{M})$ and forskolin $(\mathrm{FSK}, 10 \mu \mathrm{M})$ for $10 \mathrm{~min}$. Amounts of Rac-GTP 
and PKA activity were determined. A control for total Rac expression (total lysates) is shown. The upper panels in (a) and (b) show typical immunoblots. The middle panel in (a) shows means \pm s.e.m. of 4 independent experiments. Results are expressed as fold activation of the control (CT) cells. The lower panels in (a) and (b) show the measurements of PKA activity obtained from 3 to 5 independent experiments (means \pm s.e.m., $n=9$ to 15 ). $p<0.05, p<0.01$ or p $<0.001$ compared with CT (Student $t$-test) c, CHO 10001 and CHO 10260 cells were stimulated with increasing concentrations of FSK for 10 min and the amounts of Rac-GTP (upper panel and lower panel left) and PKA activity (lower panel right) were determined. Lower panels, values are means \pm s.e.m ( $n=9$ to 12 ). ns, non significant; CT, control untreated cells. $\mathrm{p}<0.001$ compared with control CHO 10001 cells (Student $t$-test).

Figure 5. Epac1 and Rap1 regulate Rac activation. a, The 5-HT4 receptor and the cAMP analogue and PKA inhibitor, Rp-cAMPS activate Rap1. CHO cells stably expressing the 5$\mathrm{HT}_{4(\mathrm{e})}$ receptor were treated with $1 \mu \mathrm{M} 5$-HT in the absence or presence of the selective 5$\mathrm{HT}_{4}$ antagonist, SB204070 $(1 \mu \mathrm{M})$ or $10 \mu \mathrm{M}$ Rp-cAMPS for $10 \mathrm{~min}$. After cell lysates were prepared, Rap1-GTP was assessed by pull down assays using the GST fusion protein containing the Rap1-binding domain of Ral-GDS followed by Western blot using an anti-Rap antibody. b, d, Constitutive activated forms of Epac and Rap1 induced Rac activation. CHO cells were transiently transfected with increasing amounts (from 2 to $8 \mu \mathrm{g}$ ) of cDNA encoding an activated version of Epac (Epac- $\Delta \mathrm{cAMP})$ (b), Q63E-Rap1 (d). In each condition, the total amount of cDNA was kept constant to $8 \mu \mathrm{g}$ by transfecting the corresponding empty vector. One day after transfection, cells were treated or not with forskolin (FSK, $10 \mu \mathrm{M}, 10 \mathrm{~min}$ ) and Rac activation was assessed by pull down experiments followed by Western blot using an anti-Rac antibody. c, 8-CPT-2Me-cAMP induced Rac activation.. Upper panel, CHO cells were transfected with $4 \mu \mathrm{g}$ of Epac WT, then stimulated with $15 \mu \mathrm{M}$ 8-CPT-2Me-cAMP for 
the indicated period of time and Rac activation was determined. Lower panel, mouse cortical neurons maintained in culture for 14 days were stimulated with the indicated concentration of 8-CPT-2Me-cAMP for $10 \mathrm{~min}$ and then Rac pull-down assays were performed. e, f, 5-HTinduced Rac activation is inhibited by a dominant negative form of Epac or RapGAP. CHO cells were cotransfected with the indicated amounts of empty vector, AU5-tagged Rac1 wild type and $\Delta 1$-148Epac or RapGAP. One day after transfection, cells were treated or not with 5HT ( $1 \mu \mathrm{M}, 10 \mathrm{~min})$ and Rac activation was determined as above. Upper panels, representative western blot are shown. Lower panels, AU5-Rac-GTP was normalized to total AU5-Rac. $\mathrm{p}<0.01, \mathrm{p}<0.001$ compared with either control cells (CT) (f) or 5-HT treated cells (e) (means \pm s.e.m; $\mathrm{n}=3$ to 4) (Student $t$-test). $\mathbf{g}$, Ras is not involved in cAMP-dependent Rac activation. Cotranfection and Rac pull down experiments were performed as in (d) and (e) using the indicated amounts of empty vector, AU5-tagged Rac1 WT and RasN17. A Western blot of the same lysates was carried out using anti-Flag, anti-HA and anti-GFP antibodies to monitor the level of expression of the transfected cDNA constructs.

\section{Figure 6. Epac1, Rap1 and Rac are involved in PKA-independent sAPP $\alpha$ secretion. a,} $\mathrm{CHO}$ cells were transiently transfected with increasing amounts (from 2 to $8 \mu \mathrm{g}$, total amount of transfected DNA was kept constant to $8 \mu \mathrm{g}$ with the empty plasmid vector) of Epac$\triangle \mathrm{cAMP}$ cDNA. One day later secreted sAPP $\alpha$ was determined by immunoblot upon $30 \mathrm{~min}$ treatment with $1 \mu \mathrm{M}$ 5-HT. b, The selective activator of Epac, 8CPT-2Me-cAMP enhanced sAPP $\alpha$ secretion. CHO and IMR32 cells were transiently transfected with $4 \mu \mathrm{g}$ of Epac WT. One day later secreted sAPP $\alpha$ was determined by immunoblot upon treatment with 8CPT2Me-cAMP $(10$ or $100 \mu \mathrm{M})$. The expression of the transfected construct was monitored using an antibody directed against GFP. CT, control untreated cells. Primary cortical neurons from 14 days in vitro were incubated overnight with 8CPT-2Me-cAMP $(10$ or $100 \mu \mathrm{M})$ and 
secreted sAPP $\alpha$ was determined as above. c, CHO cells were transfected with $8 \mu \mathrm{g}$ of empty vector or Q63E-Rap1. Cell treatment and immunoblots were performed as in (a). d, A dominant negative form of Epac ( $\Delta 1$-148Epac) and RapGAP block sAPP $\alpha$ secretion. CHO cells were cotransfected with the empty vector $(4 \mu \mathrm{g})$, or AU5-tagged Rac1 WT $(4 \mu \mathrm{g})$ and $\Delta$ 1-148Epac $(4 \mu \mathrm{g})$ or RapGAP $(4 \mu \mathrm{g})$. One day after, cells were stimulated with $1 \mu \mathrm{M}$ 5-HT for $30 \mathrm{~min}$ and $\mathrm{sAPP} \alpha$ secretion was determined as in (a). The expression of the transfected constructs were monitored using antibodies directed against the different epitopes. e, Rac regulates sAPP $\alpha$ secretion. Cells were transiently transfected with $8 \mu \mathrm{g}$ of RacN17 or RacV12, or vector alone. Cell treatment and immunoblots were performed as above. Corresponding cell lysates were assayed for Rac-GTP by affinity precipitation.

Figure 7. Model of Rac activation by cAMP. Stimulation of Gs coupled receptor such as the 5-HT 4 receptor activates the adenylyl cyclase which increases intracellular cAMP levels Subsequent activation of Epac1 increases Rac activation via Rap1. In the case of the 5-HT4 receptor this novel signalling pathway is involved in APP processing.

\section{SI Figure 1. The 5-HT4 receptor regulates Rap1 and Rac activities and sAPP $\alpha$ secretion} in IMR32 neuroblastoma cells. a, The 5-HT4 receptor activates Rap1. IMR32 cells were treated with a selective $5-\mathrm{HT}_{4}$ agonist, prucalopride $(1 \mu \mathrm{M})$ or forskolin $(\mathrm{FSK}, 10 \mu \mathrm{M})$ for 10 min and the amount of Rap-GTP was determined by pull down experiments followed by a Western blot using an anti-Rap antibody. b, d, Constitutive activated forms of Epac and Rap1 induced Rac activation and SAPP $\alpha$ secretion. IMR32 cells were transiently transfected with 8 $\mu \mathrm{g}$ of cDNA encoding an activated version of Epac (Epac- $\Delta \mathrm{cAMP})$, Q63E-Rap1, or V12Rac. The total amount of cDNA was kept constant to $8 \mu \mathrm{g}$ by transfecting the corresponding empty 
vector. One day after transfection, cells were treated or not with prucalopride $(1 \mu \mathrm{M})$ and Rac activation or sAPP $\alpha$ release were assessed by pull down experiments and immunoblots, respectively. c, 8CPT-2Me-cAMP induced sAPP $\alpha$ secretion in IMR32 cells. Cells were treated with prucalopride $(1 \mu \mathrm{M})$ or $8 \mathrm{CPT}-2 \mathrm{Me}-\mathrm{cAMP}(10$ or $100 \mu \mathrm{M})$ for $3 \mathrm{~h}$ and secreted sAPP $\alpha$ was determined as above. 
a

CHO cells

CT $\quad 5-\mathrm{HT} \quad \mathrm{H} 89 \quad 5 \mathrm{HT}+\mathrm{H} 89$

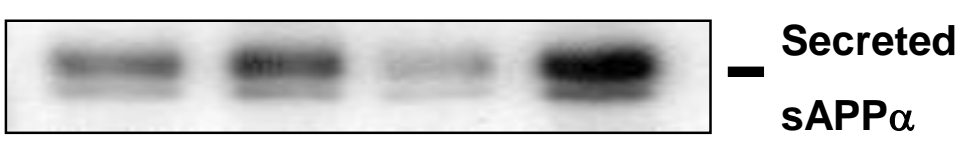

C

Primary neurons

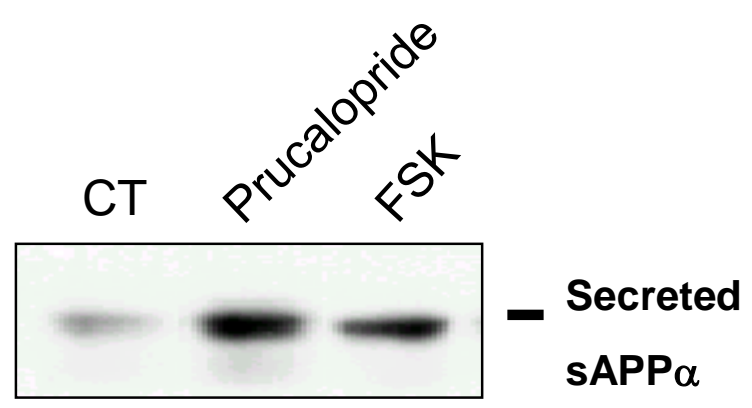

b

Primary neurons

- $+\quad+\quad$ ML10302

$-\quad+\quad+\quad+$ GR113808
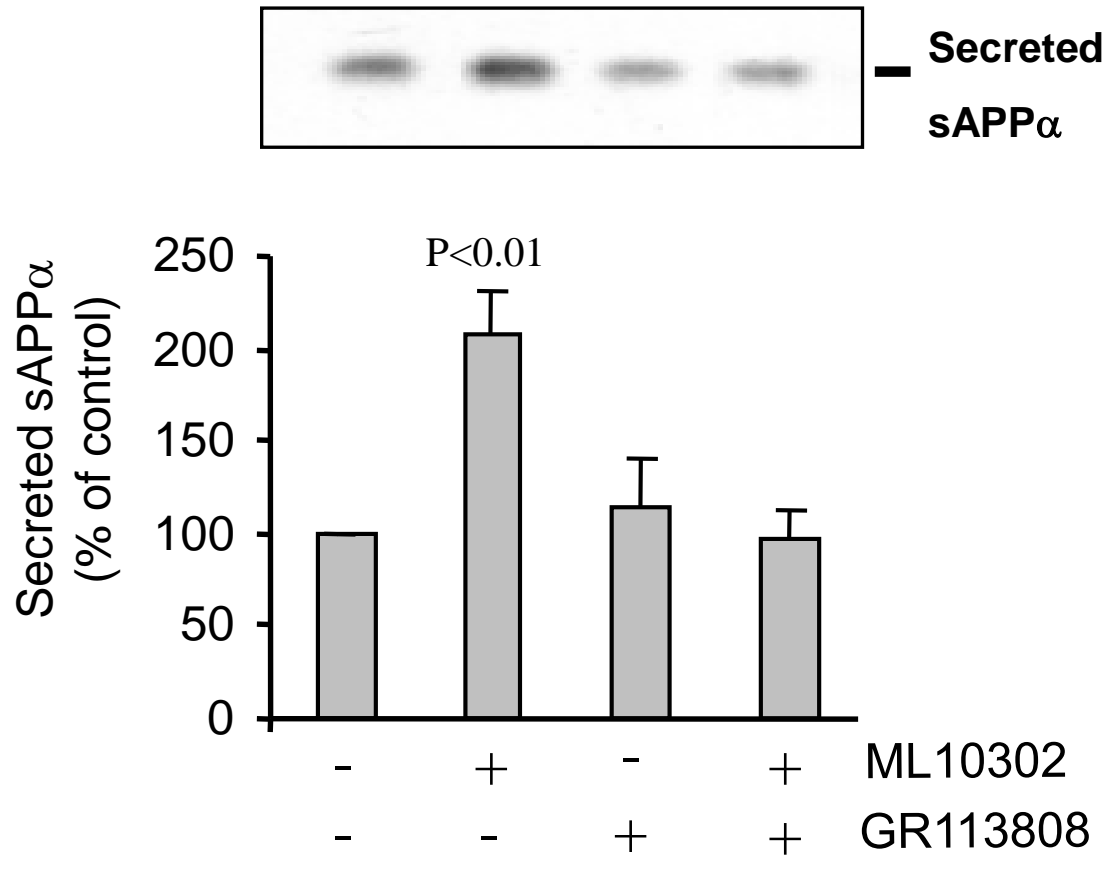
a

\section{CHO cells}

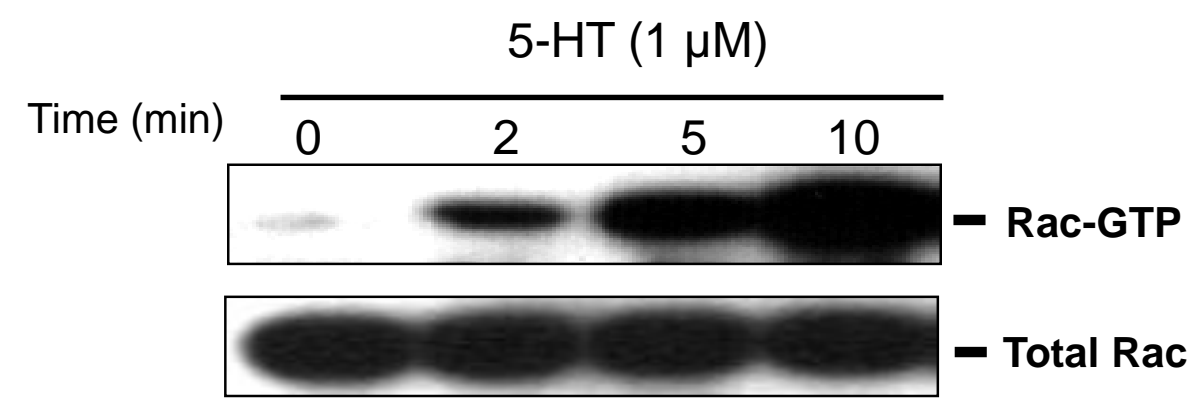

C

\section{CHO cells}

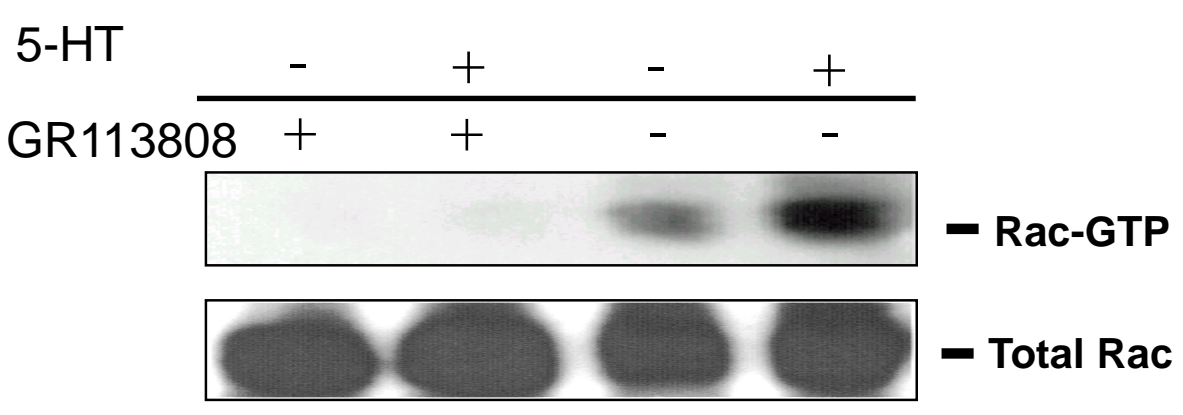

b

Fig. 2

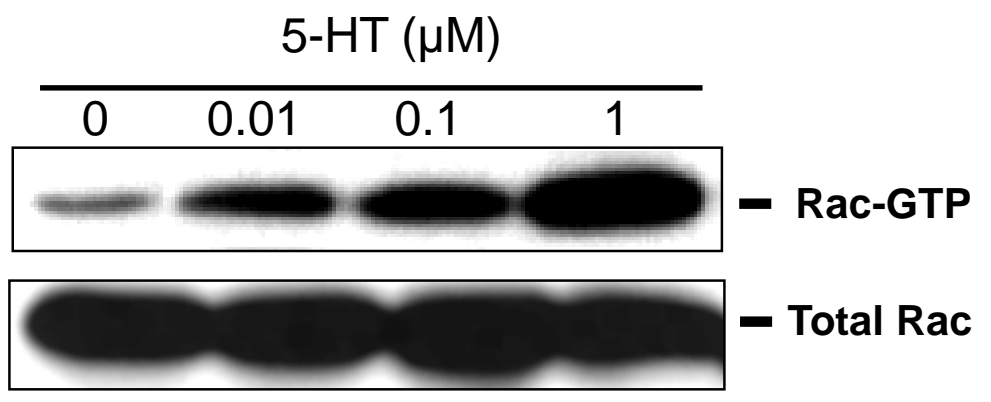

d

\section{Primary neurons}

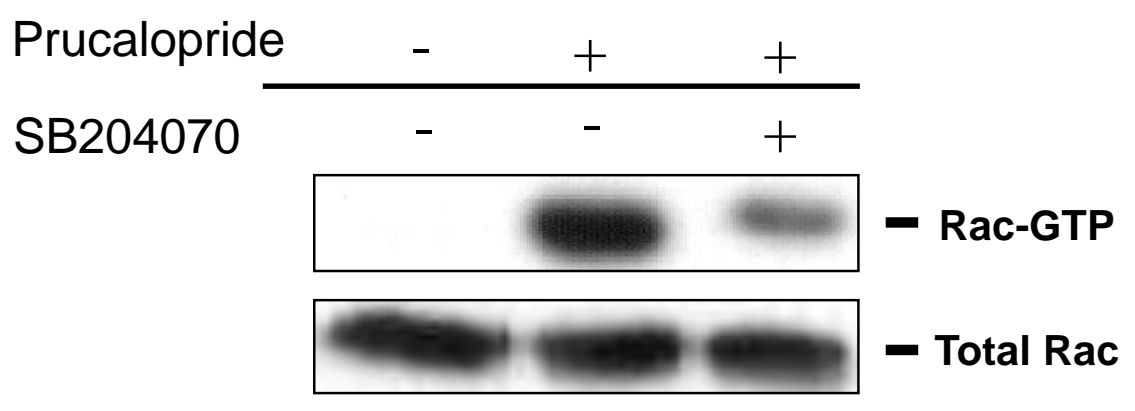

e

IMR32 neuroblastoma cells
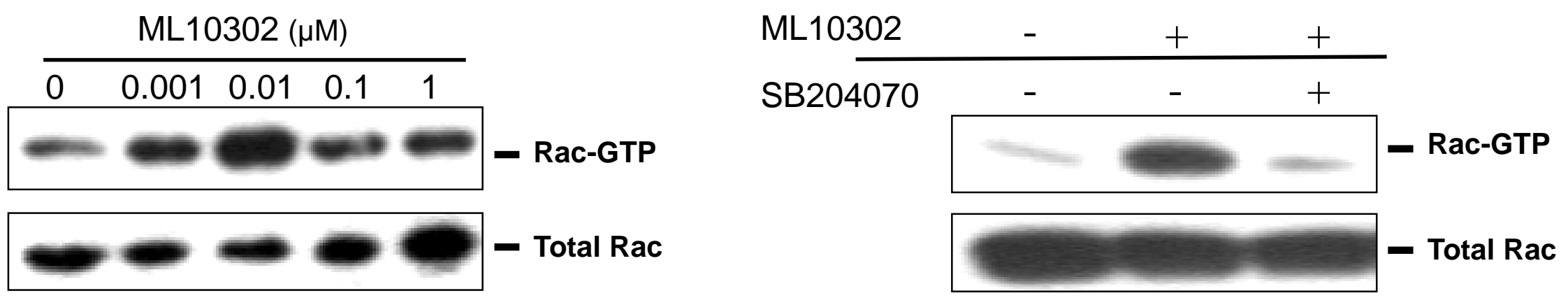
a $\quad \mathrm{CHO}$ cells
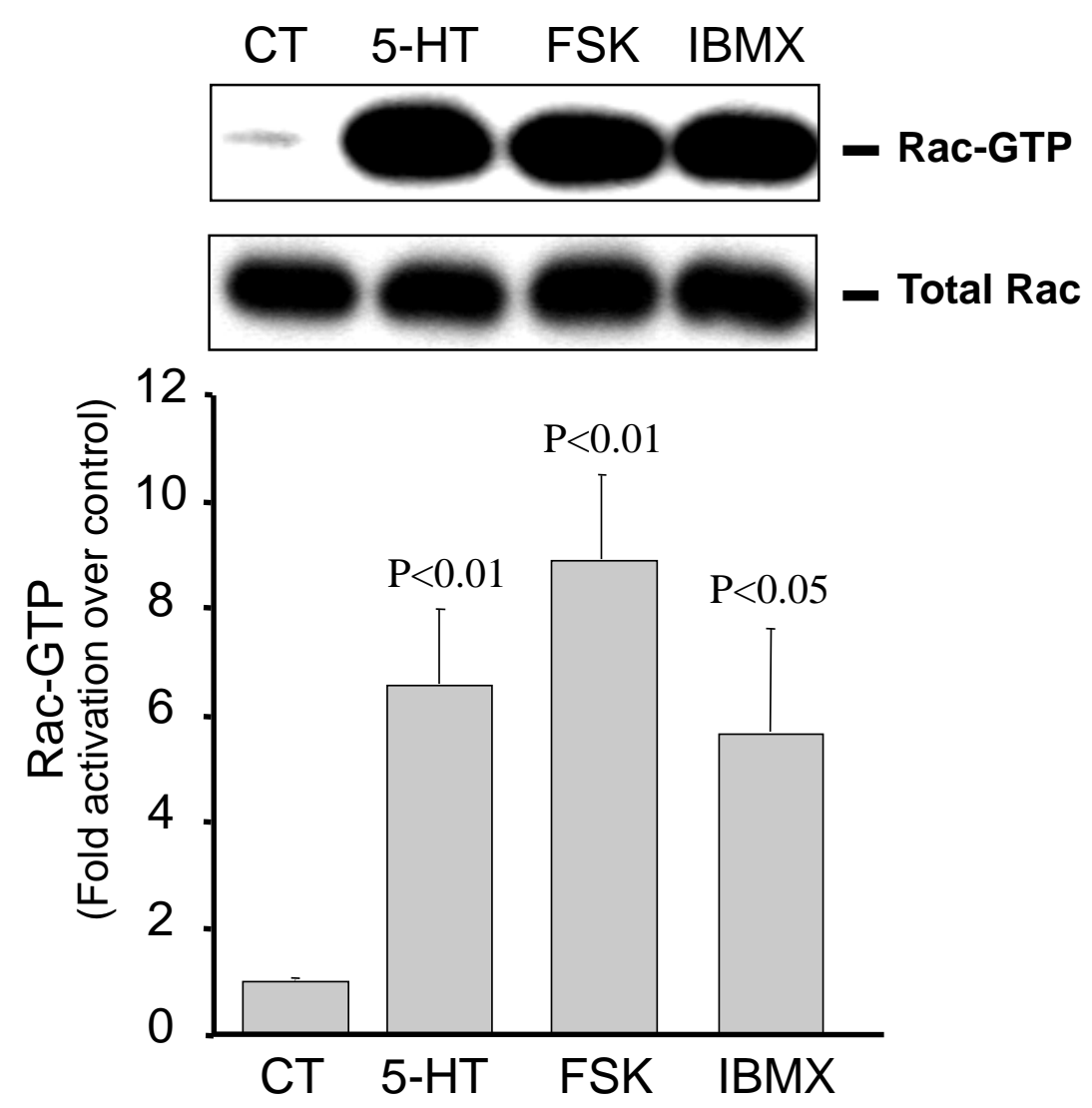

C

IMR32 neuroblastoma cells

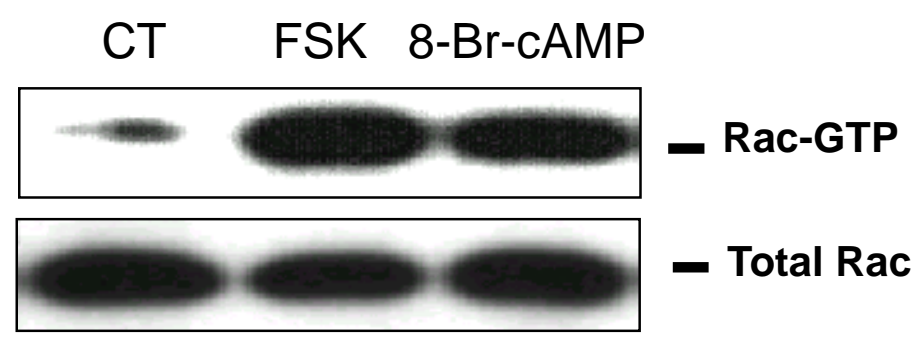

b

\section{CHO cells}

\section{Fig. 3}

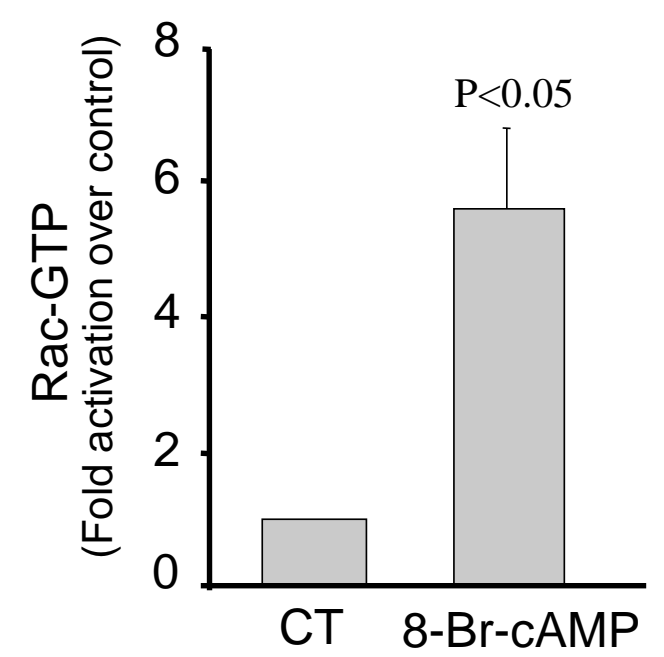

d

Primary neurons

CT Prucalopride FSK

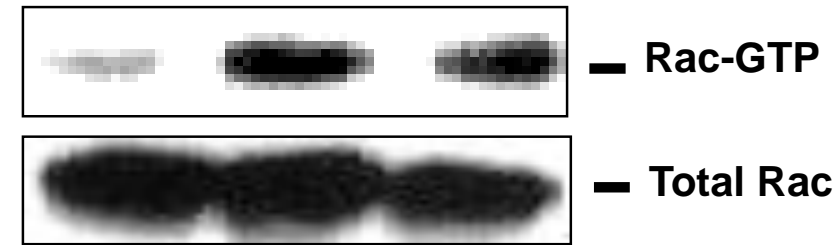


a
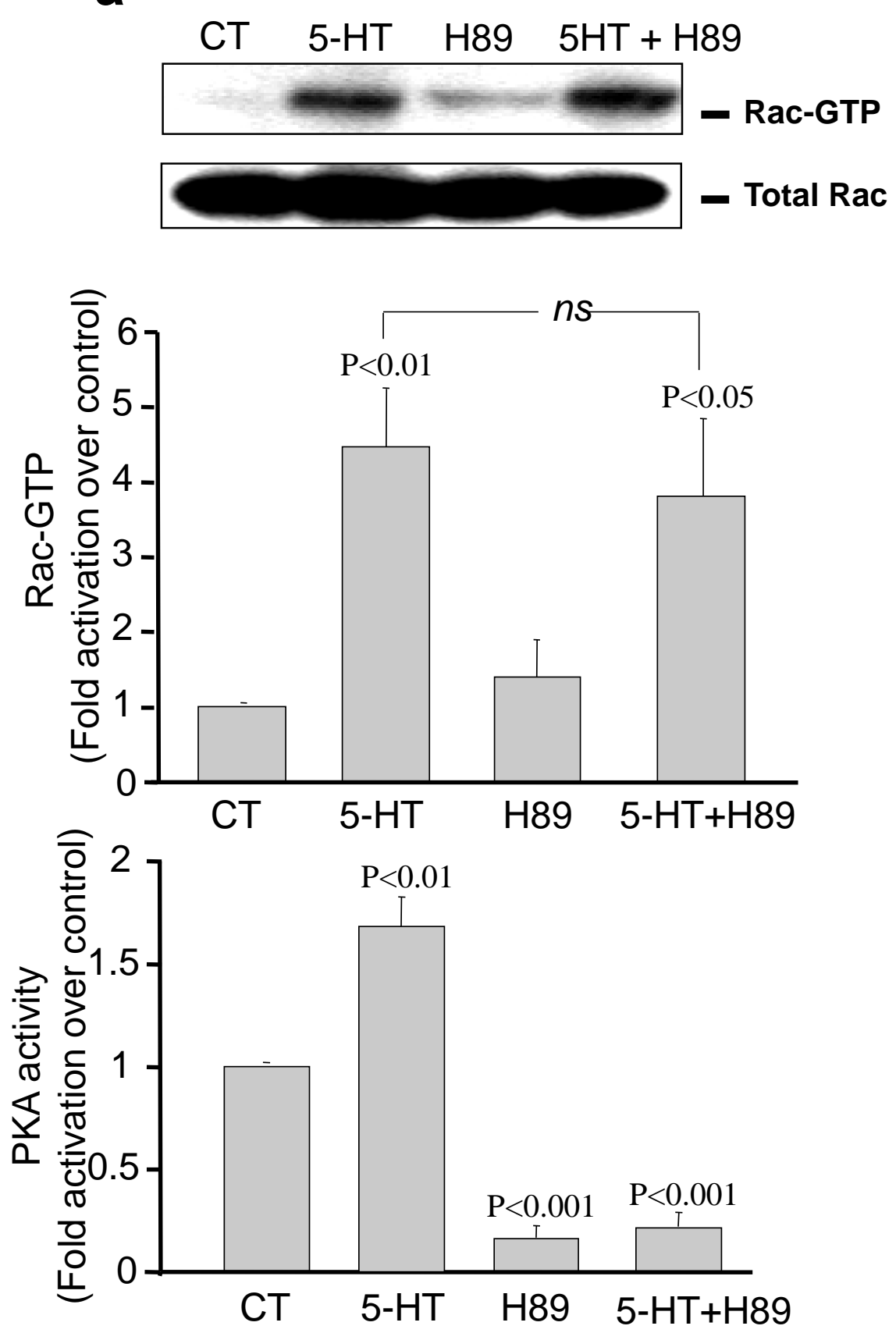

b
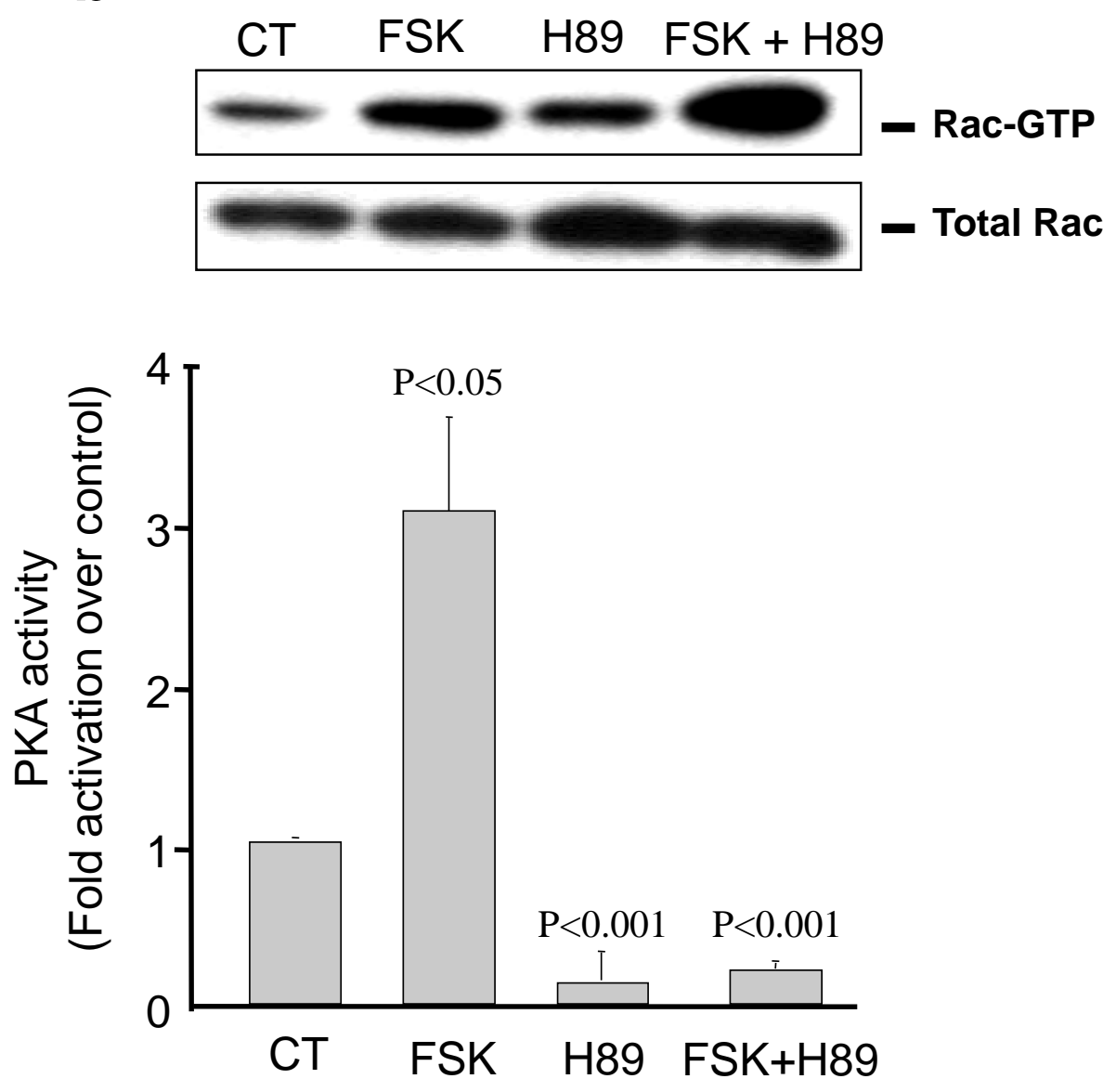
C

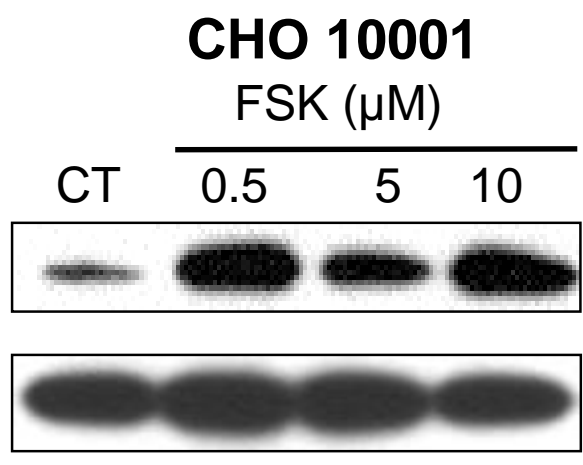

CHO 10001

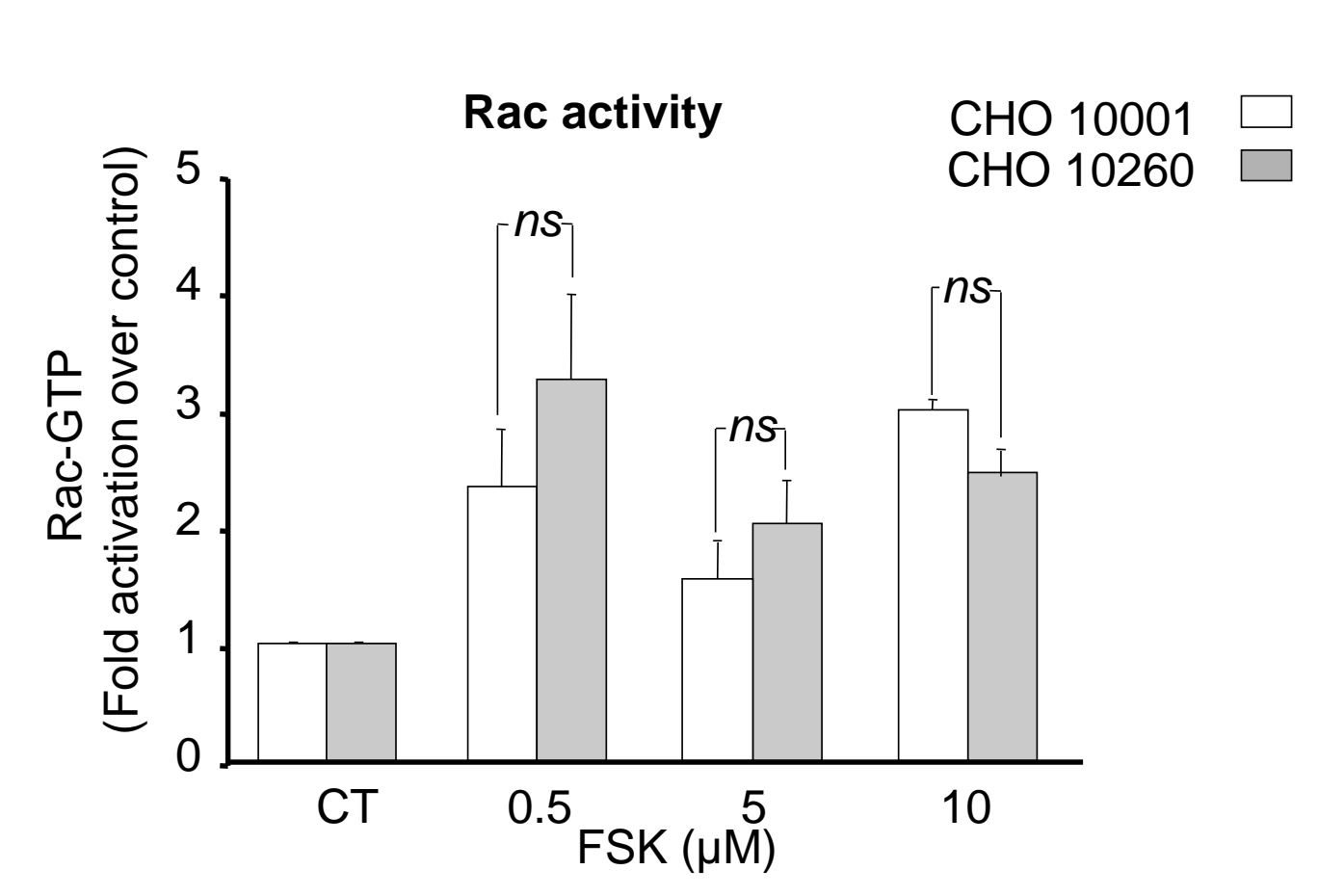

CHO 10260

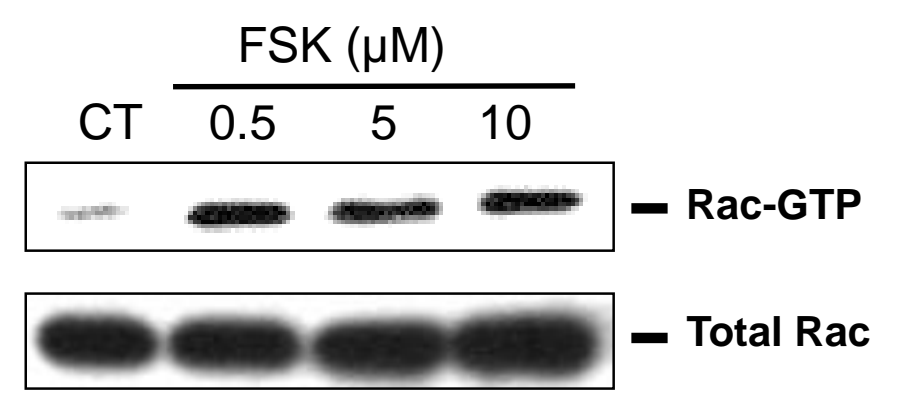

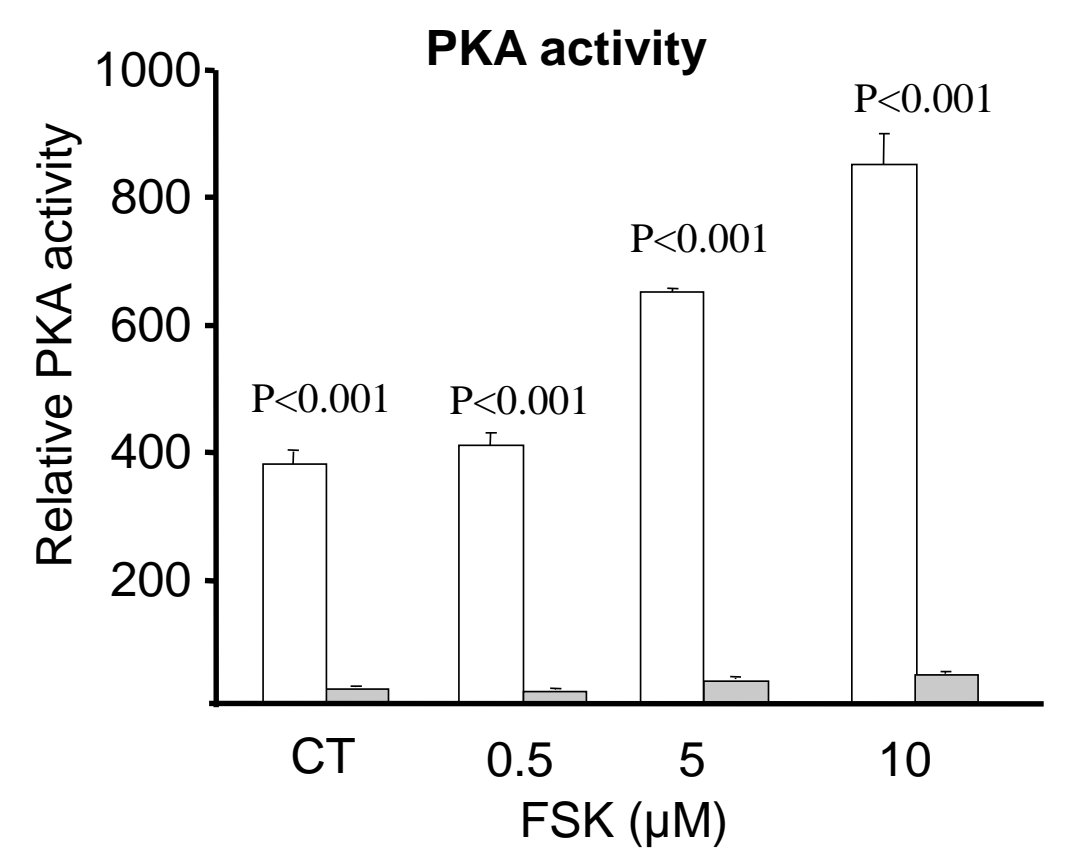

Fig. 4 
a

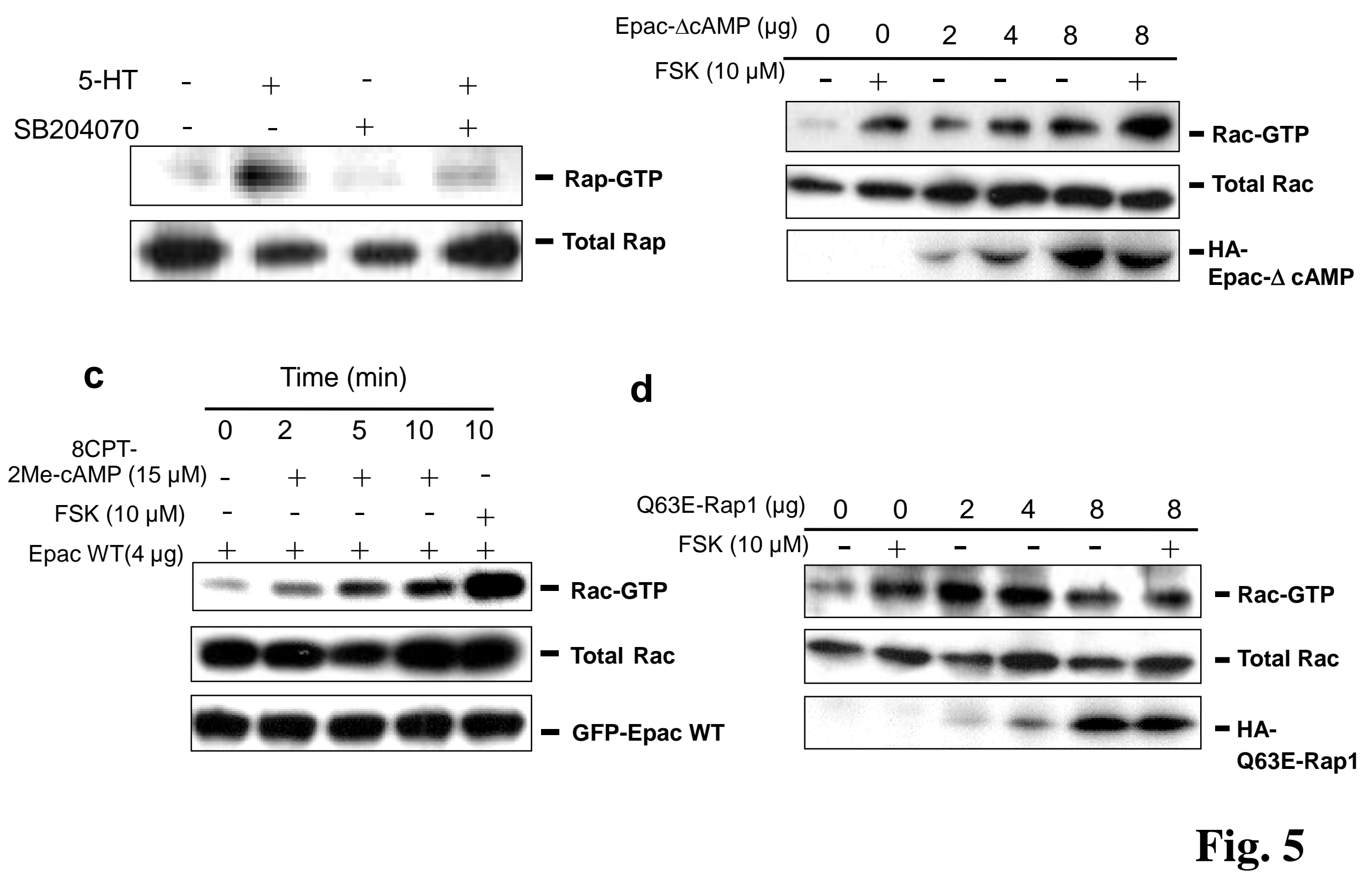


e

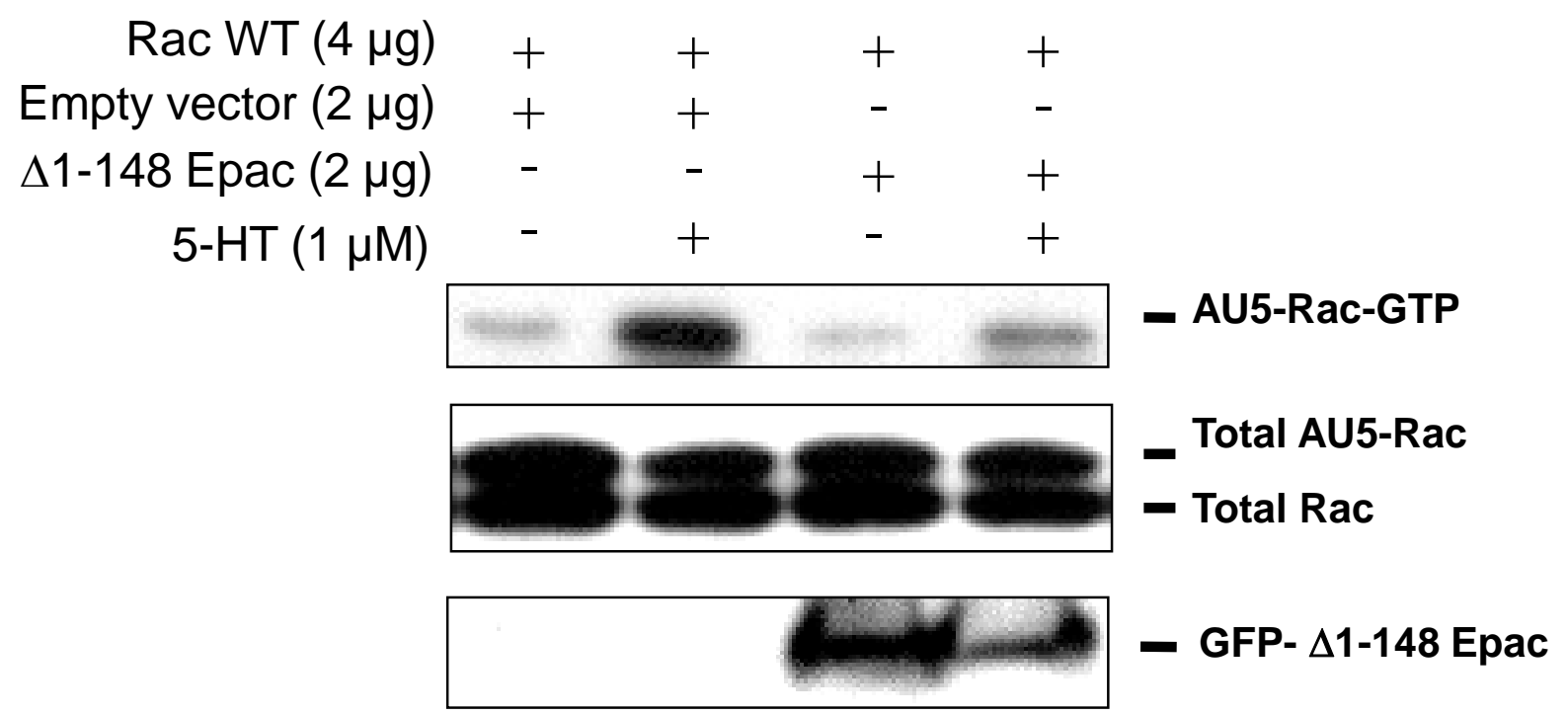

f

$\begin{array}{rcccc}\text { Rac WT }(4 \mu \mathrm{g}) & + & + & + & + \\ \text { Empty vector }(2 \mu \mathrm{g}) & + & + & - & - \\ \text { RapGap }(2 \mu \mathrm{g}) & - & - & + & + \\ \text { 5-HT }(1 \mu \mathrm{M}) & - & + & - & +\end{array}$
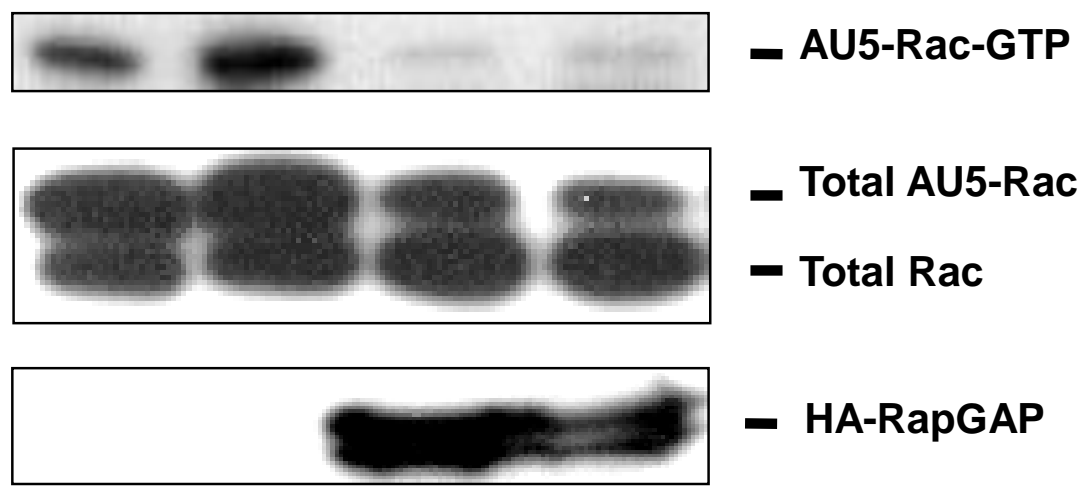
g

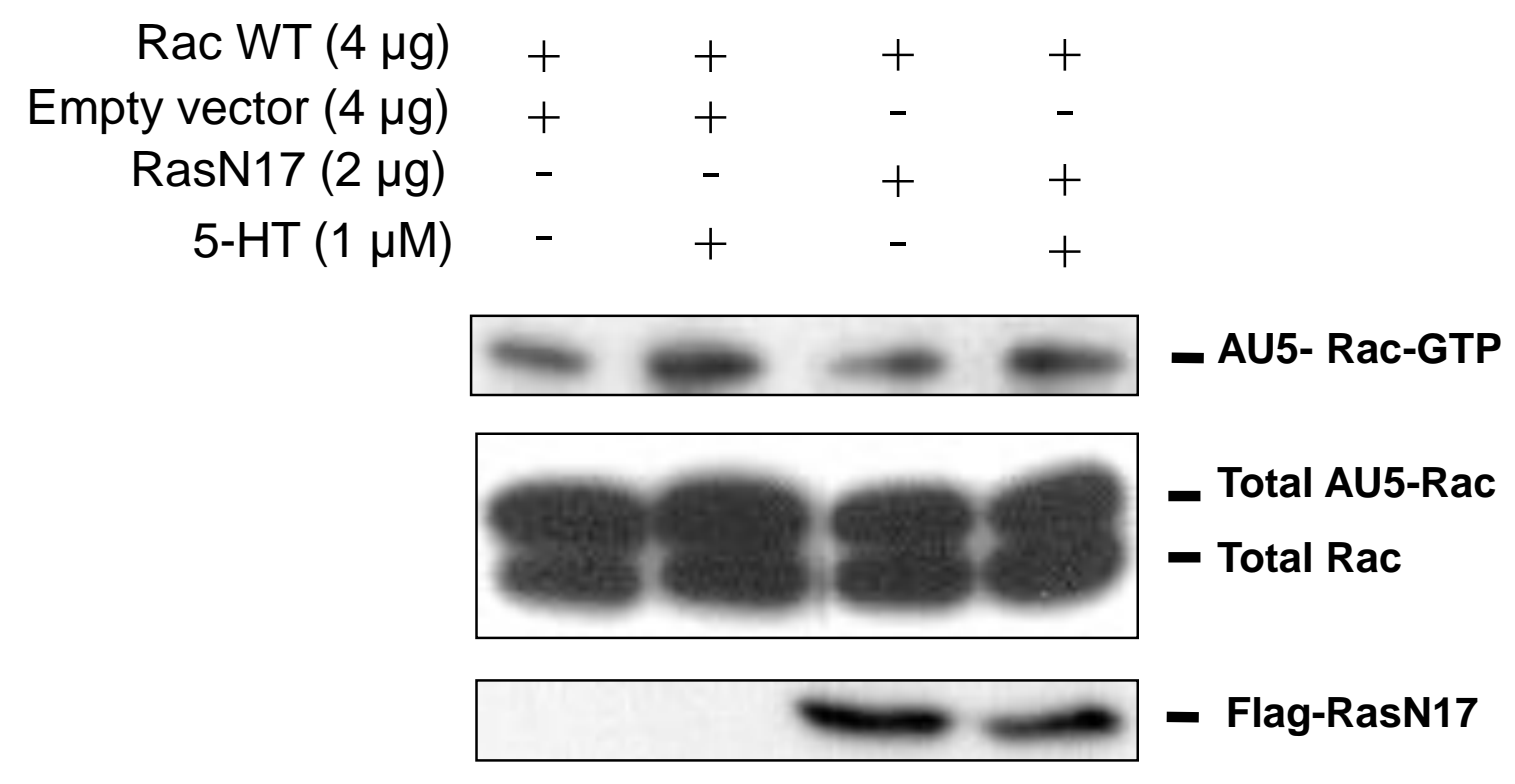


a

$$
\begin{aligned}
& \begin{array}{ccccccc}
\operatorname{Epac}-\Delta \text { cAMP }(\mu \mathrm{g})- & - & 2 & 4 & 8 & 8 \\
\hline 5-H T(1 \mu M) & - & + & - & - & & +
\end{array} \\
& 5-\mathrm{HT}(1 \mu \mathrm{M}) \quad-\quad+\quad-\quad-\quad-\quad+
\end{aligned}
$$

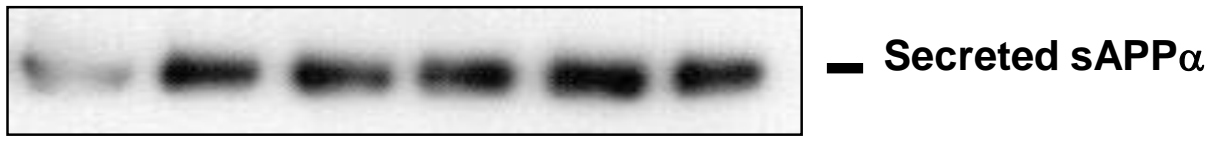

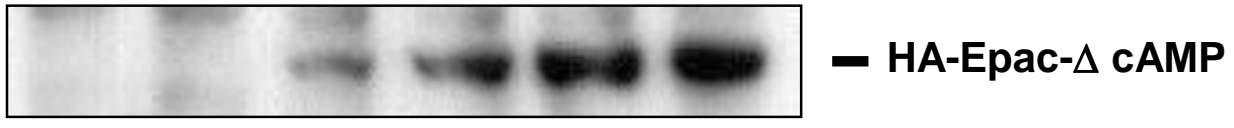

b

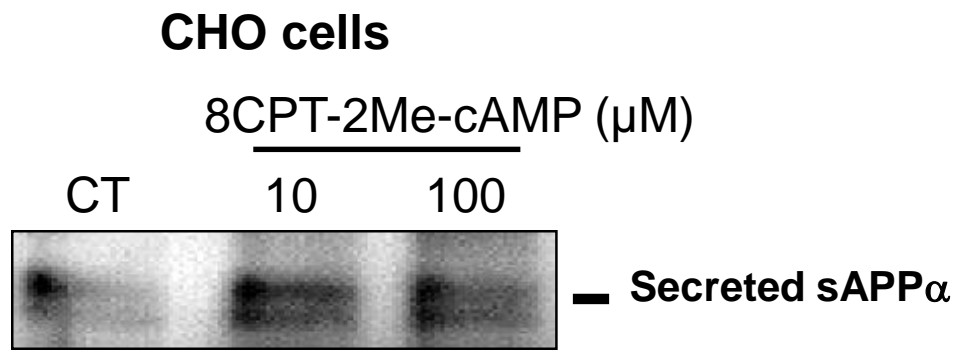

C

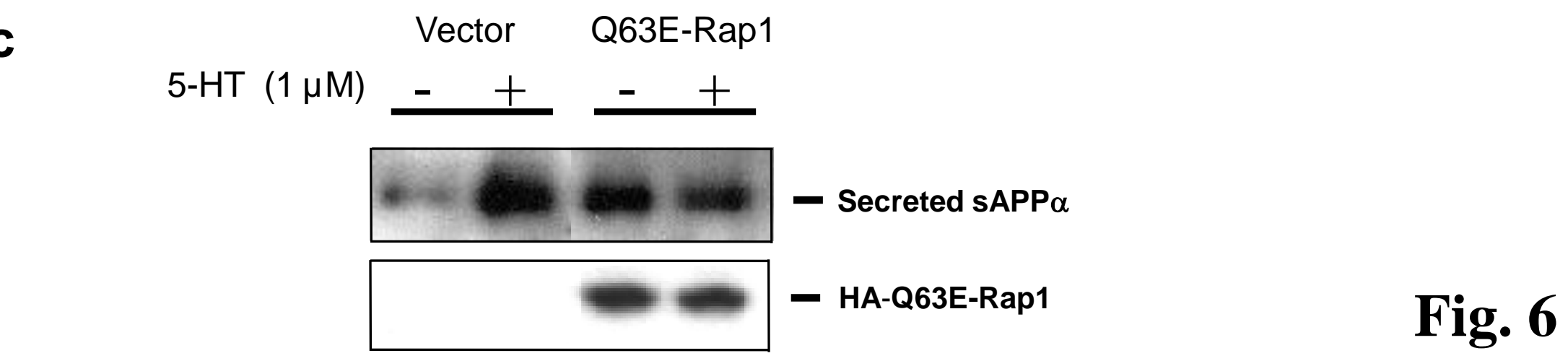

IMR32 neuroblastoma cells

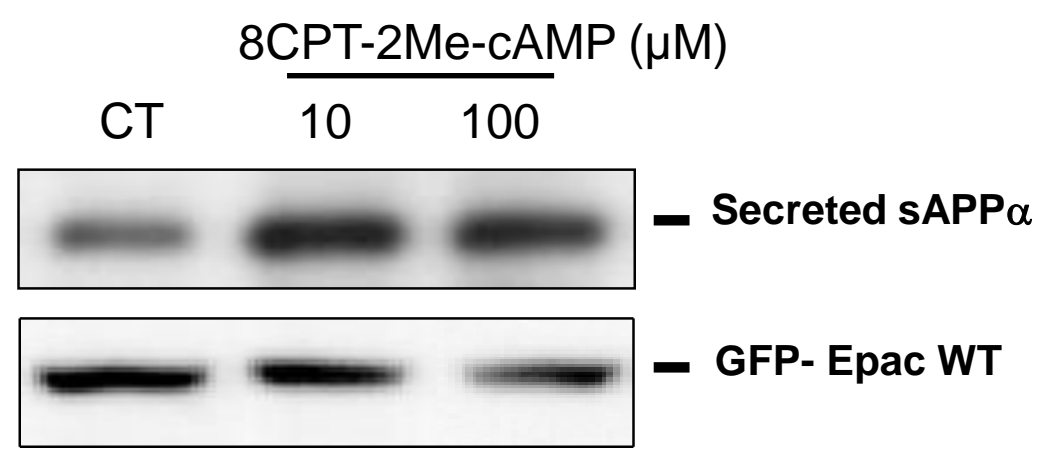


d

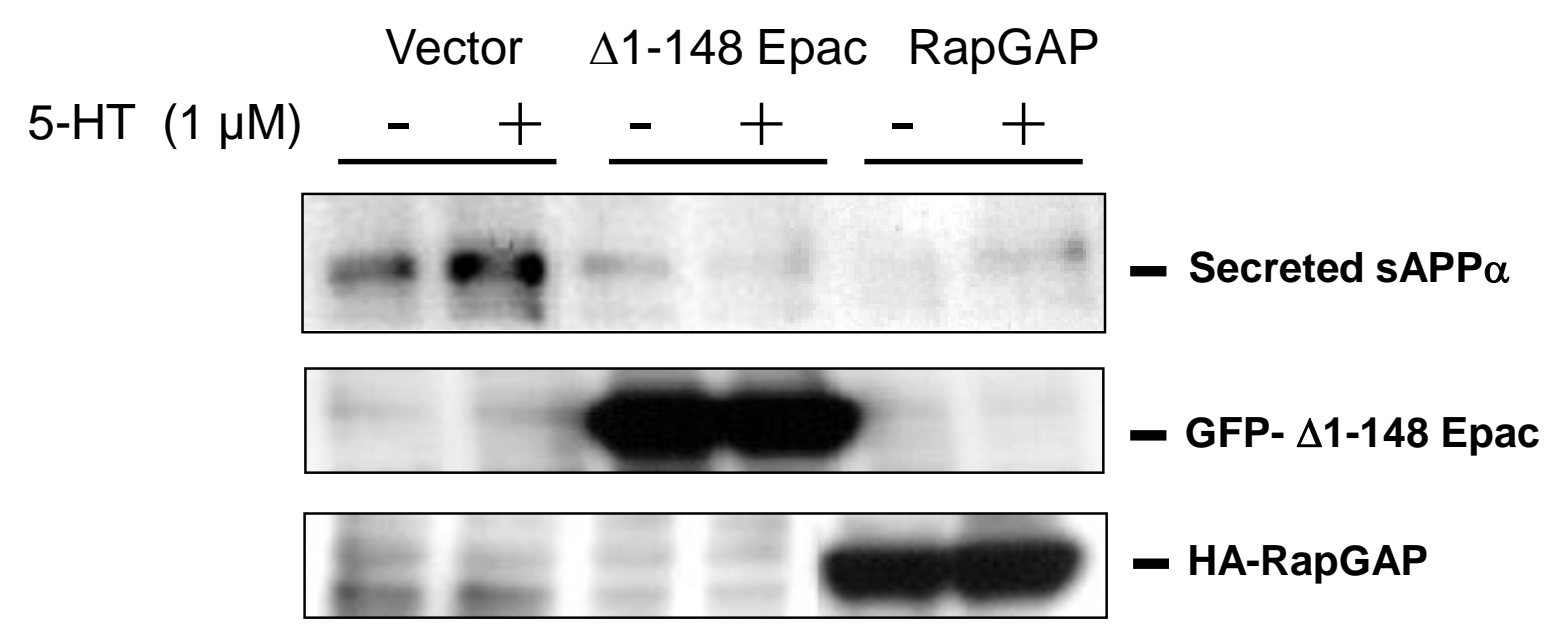

e
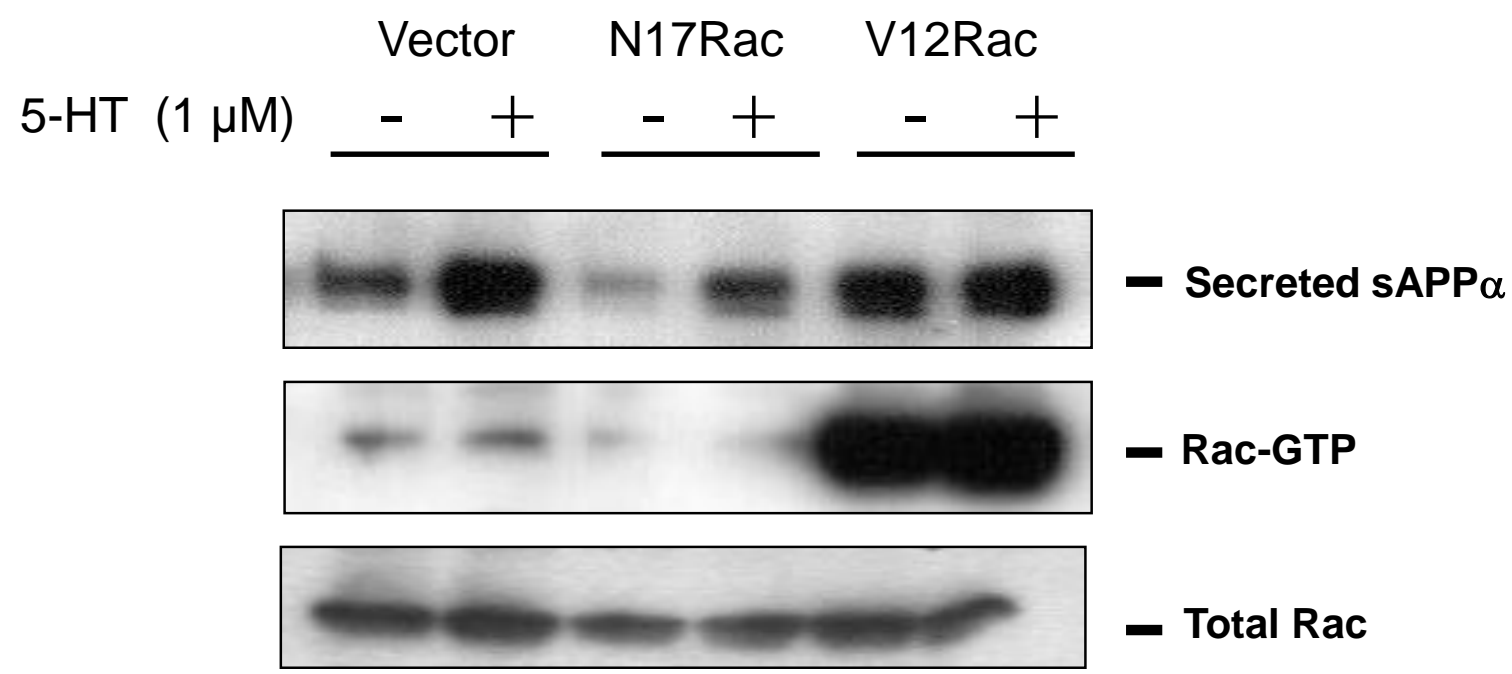


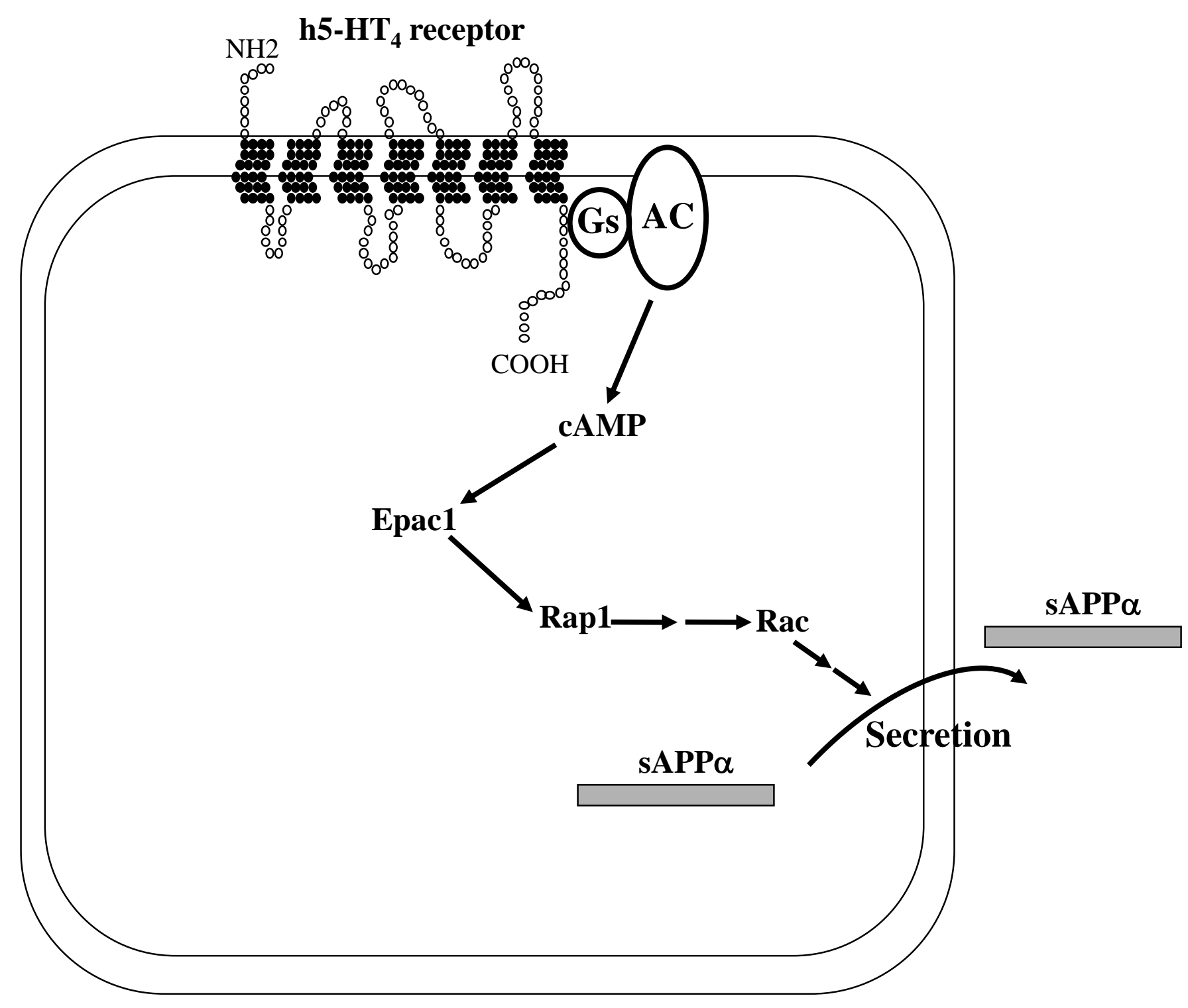

Fig. 7 
a

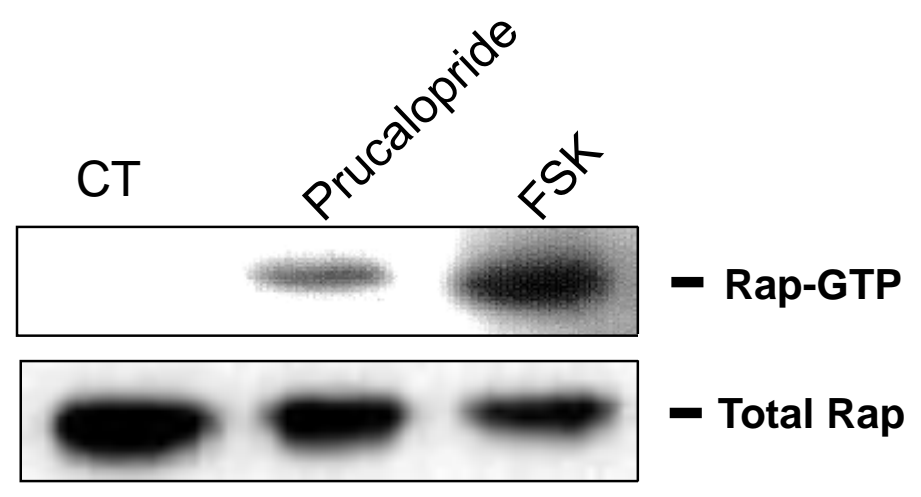

b

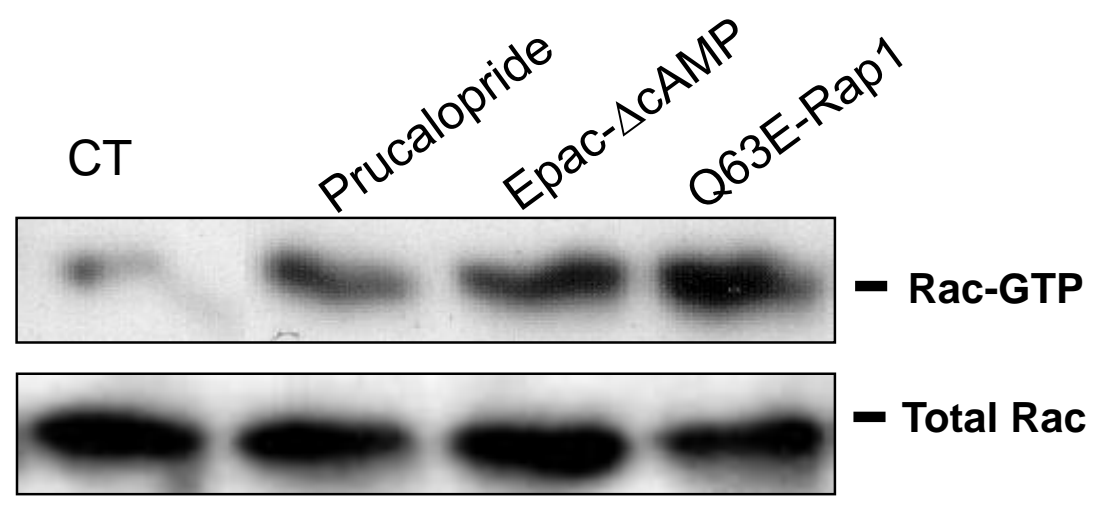

C

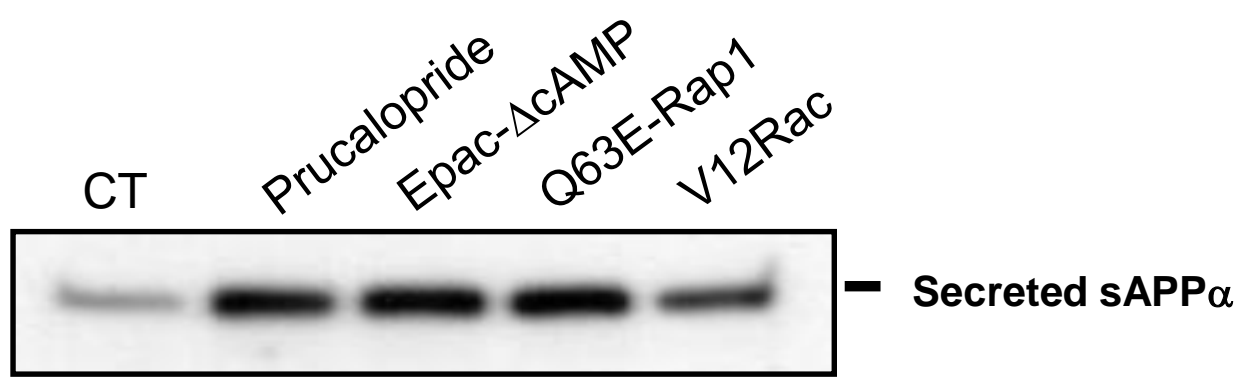

